\title{
Las autorizaciones administrativas: bases conceptuales y jurídicas
}

\section{Administrative licences: conceptual and legal basis}

Jaime Arancibia Mattar*

Este trabajo aborda la naturaleza jurídica, características y fundamentos de las autorizaciones administrativas. Además, analiza la relación jurídica autorizatoria y sus derechos y obligaciones. Finalmente, distingue entre la autorización y figuras similares como las legalizaciones ope legis, las concesiones y los actos regulatorios.

Palabras clave: autorización, concepto, fundamentos, características, estabilidad.
This paper addresses the legal nature, characteristics and rationale of administrative licences. In addition, it analyzes the legal licesing relationship and its rights and obligations. Finally, it distinguishes between licences and similar figures such as ope legis legalizations, concessions and regulatory decisions.

Keywords: licences, concept, rationale, characteristics, stability.

\section{Introducción}

Este trabajo pretende contribuir a la discusión sobre la naturaleza, contenido y características diferenciadoras de los actos administrativos autorizatorios. La necesidad de definir parámetros teóricos sobre este asunto es relevante a la luz del aumento de conflictos jurídicos asociados a esta técnica.

En algunos casos, esta conflictividad se debe a la confusión legislativa y jurisprudencial del acto autorizatorio con títulos habilitantes similares. La autorización administrativa ha sido confundida, por ejemplo,

\footnotetext{
* Profesor de Derecho Administrativo, Universidad de los Andes, Santiago, Chile. Dirección postal: Mons. Álvaro del Portillo 12.455, Las Condes, Santiago de Chile. Correo electrónico: jarancibia@uandes.cl. Este artículo fue escrito en el marco del Proyecto Fondecyt Regular N 1181593, sobre "La potestad de autorización administrativa: fundamentos dogmáticos, régimen y problemas en el ordenamiento jurídico chileno", en el que el autor es investigador responsable. El autor agradece especialmente al profesor Jaime Phillips Letelier por sus valiosas sugerencias para este trabajo.
}

Artículo recibido el 22 de septiembre de 2020 y aceptado el 7 de diciembre de 2020 . 
con actos de concesión ${ }^{1}$, autorización demanial², habilitación meramente legal $^{3}$, y acreditación no habilitante ${ }^{4}$. En otros casos, el problema obedece a la falta de claridad respecto de la precariedad o intangibilidad de los derechos y cargas que surgen del régimen autorizatorio. De otro lado, la noción de la técnica autorizatoria como mero levantamiento de una prohibición parece cuestionable ante lo que parece ser, más bien, la legalización de una actividad sujeta a un modus anterior y posterior a su realización.

En razón de lo anterior, el presente trabajo abordará la potestad de autorización administrativa bajo la perspectiva del derecho administrativo general, enriquecida por los ejemplos que plantea su aplicación sectorial. Específicamente, el texto analizará su naturaleza jurídica, características y fundamentos. Posteriormente, nos detendremos en la relación jurídica autorizatoria y los problemas que plantea en el derecho nacional. Para terminar, abordaremos las distintas especies de autorizaciones administrativas y la diferencia entre el genus autorizatorio y las figuras jurídicas colindantes como las legalizaciones ope legis, las concesiones y los actos regulatorios.

\section{Naturaleza jurídica y características de las autorizaciones adminis- trativas}

Sabido es que la naturaleza de los actos administrativos guarda una estrecha relación con la finalidad inmediata de las normas legales que ejecutan. Es así como existen actos administrativos de policía, empresariales, tributarios, prestacionales y de organización interna. En particular, los actos administrativos de policía son aquellos que velan por el cumplimiento de leyes que imponen obligaciones de dar, hacer, no hacer para prevenir daños o asegurar interacciones eficientes en relaciones que presentan riesgos ciertos de lesión o costos de transacción altos ${ }^{5}$.

En particular, una norma imperativa puede imponer al ejercicio de un derecho un modo, entendido este como un tipo de carga o deber jurídico que debe observar quien ejerce un derecho para satisfacer el interés de un tercero' ${ }^{6}$. Si bien la figura modal ha estado históricamente asociada al beneficiario de una liberalidad ( $v$. gr. testamento, donación), pensamos que no existen impedimentos para aplicarlo en iguales términos al titular de un derecho propio (no de una liberalidad) cuyo ejercicio produce externalidades negativas de interés público.

\footnotetext{
1 Comisión v Bélgica (2018).

2 Ley $\mathrm{N}^{\circ}$ 19.542, de 1997.

3 Nos referimos a las autorizaciones legales o generales infra en el acápite VI C.

4 Algunas de las acreditaciones en materia universitaria reguladas por la Ley $N^{\circ} 20.129$, de 2006.

5 Franco 2017, 221: "En ella [actividad de policía] se agrupan toda una serie de potestades administrativas que inciden sobre la libertad (la potestad autorizatoria...), y en la que al título jurídico que legitima la intervención pública es el concepto amplio de orden público".

6 Giorgianni 2018, 36.
} 
En el caso del modo autorizatorio, ese gravamen consiste en obtener previamente la dictación de un acto administrativo -autorización- que dé por cumplidos los requisitos para realizar la actividad. Tenemos, entonces, que la autorización no es un acto administrativo que levanta una prohibición -como suele repetirse casi de modo mecánico y unánime-, porque la norma que la exige no es prohibitiva sino imperativa; no obliga a "no hacer" la actividad sin autorización sino a hacerla con autorización. Lo contrario significaría sostener que toda obligación modal envuelve una obligación negativa o prohibición de desobedecer el modo, lo que resulta ciertamente forzado y ajeno a la distinción de las normas que mandan, prohíben o permiten.

El ejercicio del derecho sin autorización no infringe, por tanto, una prohibición sino el mandato legal de ejercerlo previa autorización; lo suspendido hasta la obtención de la licencia no es el ejercicio del derecho sino que el ejercicio legal del mismo. En palabras de Franco, "apelar a la idea de prohibición relativa bajo reserva de autorización supone una negación de la libertad y del derecho del operador a entrar y salir del mercado"7, lo que en Chile sería inconstitucional.

Por lo mismo, la autorización consiste en un acto administrativo que legaliza el ejercicio de un derecho para el titular que cumple las conditio iuris exigidas, mientras las cumpla o por el tiempo que el legislador disponga. De acuerdo con esta definición, los elementos esenciales del acto autorizatorio son: a) la titularidad privada de un derecho cuyo ejercicio está sujeto a un modo o carga autorizatoria; b) el cumplimiento de los requisitos habilitantes para la obtención de la autorización; y c) la verificación fundada ${ }^{8}$ del cumplimiento de las condiciones necesarias para otorgar la autorización ${ }^{9}$. A lo anterior podríamos añadir un cuarto elemento, de carácter doméstico, relativo a que tanto los requisitos condicionantes como la potestad autorizatoria deben ser de fuente legal, de conformidad a los artículos $19 \mathrm{~N}^{\circ} 21, \mathrm{~N}^{\circ} 26$ y 7 inciso $2^{\circ}$ de la Constitución.

En cuanto a sus características, podemos señalar que la autorización es una potestad de policía en sentido funcional; administrativa o judicial (jurisdicción voluntaria) en el plano orgánico; en principio, no contenciosa en el ámbito subjetivo; disponible en cuanto a su objeto e indisponible en cuanto al interés tutelado. Puede ser también de operación o de funcionamiento, según si se despliega sobre un acto singular 0 una actividad ${ }^{10}$; de trámite 0 terminal, según si el ejercicio del derecho autorizado es accesorio o principal a una actividad; y declarativa en cuanto a su objeto. Además, puede desplegarse sobre las aptitudes de una actividad (ob factam), cosa (ob rem) o sujeto

\footnotetext{
7 FrANCO 2017, 300.

8 Dictamen No 40.152 (2011).

9 Este elemento está presente también en la definición de autorización empleada por la Unión Europea en sus directivas. Directiva N²006/48/CE, de 2006.

10 Laguna de Paz 2006, 72.
} 
(ob personam), lo que es determinante para decidir su transmisibilidad ante el cambio de titular de la actividad.

En cuanto a su modalidad de ejercicio, la potestad autorizatoria es siempre reglada, aunque con mayor o menor margen de apreciación, pues la autoridad está obligada a otorgarla en caso de verificarse las condiciones exigidas; de no hacerlo, incurriría en una omisión antijurídica ${ }^{11}$ o privación indirecta del derecho preexistente. Asimismo, en relación con el precepto legal que impone los requisitos, la jurisprudencia contralora ha declarado que "al ser una norma que introduce limitaciones al ejercicio de un derecho y por tanto excepcional, ha de aplicarse restrictivamente" ${ }^{12}$.

Cabe aclarar aquí que la expresión "podrá autorizar", presente en algunas leyes, no atribuye discrecionalidad al órgano competente, pues corresponde más bien a la necesidad de verificar el cumplimiento de requisitos objetivos de otorgamiento adicionales a los exigidos al solicitante, como la suficiencia de recursos ${ }^{13}$. La potestad, por tanto, continúa siendo reglada.

En cuanto a su origen, el derecho cuyo ejercicio está sujeto a autorización puede ser reconocido o constituido por el legislador. Son objeto de reconocimiento los derechos esenciales que emanan de la naturaleza humana, mientras que son constituidos, por ejemplo, los derechos de una concesión estatal que requieren igualmente de autorización para ser ejercidos. Por ejemplo, la concesión de uso de faja adyacente de camino público para instalaciones de servicios de interés público puede estar sujeta a una autorización de la Dirección de Vialidad ${ }^{14}$.

Por otro lado, puede ocurrir que un acto no sea autorizatorio del ejercicio de un derecho pero sí de un atributo esencial del mismo, lo que nos lleva a sostener, por último, que la naturaleza autorizatoria de un acto es relativa o predicable únicamente respecto de la facultad específica cuyo ejercicio autoriza. Por ejemplo, la actividad universitaria no está supeditada al acto de acreditación institucional de "excelencia" o "avanzada", pero sí al derecho a "impartir nuevas carreras o programas de estudio..."

\section{Fundamentos del régimen autorizatorio}

La técnica autorizatoria, como dijimos en el acápite anterior, corresponde a una potestad administrativa de policía que podríamos calificar de ex ante,

\footnotetext{
11 Corte Suprema. Rol N 10.859-1987, sobre rechazo injustificado de recepción de obras por parte del Director de Obras Municipales, c. $5^{\circ}$.

12 Dictamen No 14.249 (2018); Dictamen N³4.124 (2002); Dictamen N 42.836 (2015).

13 Por ejemplo, artículos 47, 100 y 167 del D.S. N 430, Ministerio de Economía, Fomento y Reconstrucción, de 1992 (autorizaciones pesqueras).

14 Art. 41 incisos $3^{\circ}$ y $4^{\circ}$ del D.F.L. N ${ }^{\circ}$ 850, Obras Públicas, de 1998. Cfr Sentencia TC Rol $N^{\circ} 1991$ (2012), c. 14․ Dictamen N²8.151 (1998); Dictamen Nº.360 (2000); Dictamen $N^{\circ} 65.813$ (2011); Dictamen No 87.452 (2015).

15 Art. 20 de la Ley N²0.129, de 2006.
} 
pues es ejercida con anterioridad a la realización de una actividad riesgosa o ineficiente ${ }^{16}$. Contrasta así con los poderes de policía ex post o ejercidos durante o después de dicha conducta. Por tanto, a la hora de identificar sus fundamentos, es preciso preguntarse por los factores que ameritan supeditar la legalidad de una actividad a la obtención de una autorización vis-à-vis la eficacia de poderes de fiscalización y corrección posteriores.

Puesto que la regulación a la que sirven los poderes de policía tiene por fin el modelamiento de los comportamientos humanos para satisfacer intereses públicos, la respuesta a esta interrogante no corresponde a los juristas sino que a los estudiosos de los niveles de riesgo del actuar humano y de los estímulos que permiten disminuirlos en ámbitos específicos. En tiempos recientes, este tipo análisis ha sido denominado economía del comportamiento ("behavioural economics") ${ }^{17}$.

Al respecto, la literatura especializada ha establecido parámetros precisos acerca de la procedencia de las autorizaciones administrativas ${ }^{18}$. Por regla general, corresponde a actividades cuya realización no autorizada hace presumir riesgos de lesión al interés social difíciles de corregir de modo eficaz y eficiente mediante la imposición de poderes correctivos menos restrictivos ${ }^{19}$. Siguiendo este criterio, por ejemplo, la Directiva Bolkestein de la Unión Europea ha dispuesto que "la autorización solo es admisible en aquellos casos en que no resultaría eficaz hacer un control a posteriori, habida cuenta de la imposibilidad de comprobar a posteriori los defectos de los servicios en cuestión y habida cuenta de los riesgos y peligros que se derivarían de la inexistencia de un control a priori"20. En igual sentido, el Tribunal de Justicia de la Unión Europea ha declarado que "el procedimiento de autorización previa solo es necesario si se considera que el control a posteriori es demasiado tardío para que su eficacia real quede garantizada y par a permitirle alcanzar el objetivo perseguido" 21.

En la práctica, el legislador ha sometido a autorización las actividades susceptibles de fallas de rendimiento y regularidad catastróficas o que generen una alta aversión social ( $v$. gr. servicios básicos)22; aquellas que solo son aceptables en menor cantidad, razón por la cual es preciso controlar el número de sujetos habilitados (v. gr. casinos) ${ }^{23}$; y otras que exigen imponer

\footnotetext{
16 Sentencia TC Rol Nº 2.841 (2015), c. $29^{\circ}$.

17 Baddeley 2017, 1.

18 Ogus 2004, 215. Höppner y KiRCHner 2015, 227-259; y DOMÉneCH 2017, 47-62.

19 Sobre la presunción del riesgo, véase Corte Suprema. Rol N²3.652-2014, c. 2, y Corte Suprema. Rol No 36.684-2017.

20 Directiva 2006/123/CE de 2006, apartado N 54.

21 Canal Satélite Digital SL v Administración General del Estado (2002), apartado №39.

22 Véase la justificación dada por el Tribunal de Justicia de la Unión Europea en el caso Asociación Profesional de Empresas Navieras de Líneas Regulares (Analir) and Others v Administración General del Estado (2001) c. 34.

23 Ogus 2004, 214.
} 
medidas preventivas ad hoc al nivel de riesgo del sujeto, según la idea de risk based regulation ${ }^{24}$.

La debida justificación del régimen autorizatorio y de sus restricciones es particularmente relevante, dado que su infracción podría dar paso a declaraciones de inaplicabilidad o de inconstitucionalidad de la ley que lo contiene.

\section{Eficacia material o necesidad del régimen autorizatorio}

A modo de referencia, el Tribunal de Justicia de la Unión Europea ha declarado la ineficacia material de autorizar la adquisición de acciones para asegurar el funcionamiento regular y continuo de empresas que no requieren semejante exigencia por razones de interés público, como una tabacalera o una entidad bancaria ${ }^{25}$. Sería innecesario también supeditar esa compra en empresas energéticas de interés público con la misma finalidad, dado que la mera adquisición de tales activos "no puede, en principio, considerarse en sí misma como una amenaza real y suficientemente grave para la seguridad del suministro de energía"26. En igual sentido, un régimen autorizatorio de líneas de cabotaje solo se justifica si se ha "constatado para cada trayecto de que se trata, la insuficiencia de los servicios regulares de transporte en el caso en que la prestación de estos se dejara únicamente a las fuerzas del mercado"27.

El instrumento autorizatorio es también innecesario cuando "duplica los controles ya efectuados en el marco de otros procedimientos" ${ }^{28}$. Por ejemplo, se ha estimado improcedente la autorización de una caja de previsión nacional para invertir en un fondo extranjero cuando esta "ya ha sido sometida a un control para ser autorizada a ejercer sus actividades, y su gestión financiera es objeto de control continuado" 29.

Sea cual fuere el estándar de riesgo que justifique la técnica autorizatoria, como dice la jurisprudencia de la Unión Europea, "el análisis del riesgo no puede basarse en consideraciones puramente hipotéticas" ${ }^{30}$. Por esta razón, el Tribunal declaró innecesario el régimen de autorización para la adquisición de acciones de servicios privados de interés público con el fin de asegurar el abastecimiento del país en caso de crisis. De acuerdo al fallo,

\footnotetext{
24 BLACK y BALDWIN 2012, 181-213.

25 Comisión con España (2000), apartado $N^{\circ} 70$.

26 Comisión v Reino de España (2008), apartado N51. Ver también Comisión con España (2000), apartado N 72; Comisión v Grecia (2012), apartado Nº9.

27 Asociación Profesional de Empresas Navieras de Líneas Regulares (Analir) and Others v Administración General del Estado (2001) consid. 34; y Naftiliaki Etaireia Thasou AE and Amaltheia I Naftiki Etaireia v Ypourgos Emporikis Naftilías (2011), apartado No 54.

28 Canal Satélite Digital SL v Administración General del Estado (2002), apartado Nº 36.

29 Comisión v Alemania (2012), apartado $N^{\circ} 32$.

30 Comisión v Alemania (2017), apartado N60. También, Comisión v Francia (2010), apartado No 91.
} 
semejante restricción era innecesaria porque no existía una "amenaza real y suficientemente grave" 31 .

\section{Límite nuclear y proporcionalidad del régimen autorizatorio}

Para ser justo, un régimen autorizatorio no solo debe ser eficaz sino respetuoso de la esencia o núcleo del derecho cuyo ejercicio ha sido condicionado, y proporcionado.

Este límite se desprende de la prohibición constitucional, dirigida al legislador, de supeditar la autorización a condiciones, tributos o requisitos que afecten ese derecho en su esencia o impidan su libre ejercicio (art. $19 \mathrm{~N}^{\circ} 26$ ). En consecuencia, la exigencia de semejantes requisitos constituiría una limitación inconstitucional del derecho que se pretende ejercer, conocida también como privación regulatoria.

Por lo mismo, el Tribunal de Justicia de la Unión Europea ha declarado que "un régimen de autorización previa no puede legitimar un comportamiento discrecional de las autoridades nacionales que pueda privar de su eficacia a las disposiciones de la Unión, en particular, a las relativas a una libertad fundamental" 32 . En este sentido, calificó de injusto un estatuto autorizatorio de adquisición de acciones de empresas energéticas con el fin de asegurar el abastecimiento del país en caso de crisis, inter alia, por "hacer que la libre circulación de capitales sea ilusoria"33.

A su vez, un estatuto de autorización es desproporcionado cuando, sin afectar el derecho en su esencia, supedita su ejercicio a requisitos, condiciones o restricciones excesivos, es decir, que van más allá de lo estrictamente necesario para satisfacer el interés público perseguido. En este sentido, la misma judicatura ha sostenido que la técnica autorizatoria es inconsistente con la libertad para prestar servicios de interés público "si, por su duración y por los gastos desproporcionados que genera, puede disuadir a los operadores de llevar adelante su proyecto" ${ }^{\prime 3}$. Al respecto, es posible identificar dos tipos de desproporción: potestativa y de requisitos.

Un primer tipo de desproporción, potestativa, consiste en someter una actividad a autorización en circunstancias de que el objetivo público podría haberse alcanzado a través de técnicas menos restrictivas, tales como comunicaciones, notificaciones fehacientes o declaraciones juradas. Por ejemplo, la jurisprudencia de la Unión Europea declaró desproporcionado el modelo autorizatorio de la participación accionaria de extranjeros en servicios

\footnotetext{
31 Comisión v Francia (2002), apartados $41^{\circ}$ y $48^{\circ}$ respectivamente. Ver también, Bordessa y otros (1995), apartado N²5; Comisión v Bélgica (2002), apartado N47; y Luisi y Carbone (1984), apartado N³4; Comisión v Portugal (2002), apartado N 45.

32 Naftiliaki Etaireia Thasou AE and Amaltheia I Naftiki Etaireia v Ypourgos Emporikis Naftilías (2011), apartado $N^{\circ} 48$.

33 ĺdem.

34 Canal Satélite Digital SL v Administración General del Estado (2002), apartado N 43.
} 
públicos privatizados con el fin de asegurar la seguridad del suministro energético. En su opinión, este objetivo podría haber sido alcanzado eficazmente mediante medidas menos restrictivas ${ }^{35}$. Lo mismo respecto de la autorización a un extranjero para adquirir una segunda vivienda, que el Tribunal descartó como indispensable para proteger la seguridad nacional porque existían intervenciones ex post menos lesivas ${ }^{36}$.

Siguiendo con este criterio, el Tribunal de Justicia de la Unión Europea ha estimado desproporcionada la autorización previa de la salida de moneda metálica, billetes de banco o cheques bancarios al portador fuera del territorio nacional para asegurar la eficacia de los controles fiscales y prevenir actividades ilícitas. A su juicio, los objetivos de prevención del fraude fiscal, el blanqueo de dinero, el tráfico de estupefacientes y el terrorismo que perseguía dicha medida podían ser satisfechos eficazmente con técnicas menos lesivas del principio de libre circulación de capitales $^{37}$.

Igualmente, Francia se allanó como demandada ante el Tribunal de Justicia de la Unión Europea por una ley que supeditó la importación y distribución de medicamentos autorizados por la Unión Europea a una nueva autorización o certificación nacional, en circunstancias que bastaba con "un control del número que figura en el acondicionamiento exterior del medicamento" 38 . Siguiendo este criterio, algunas comunidades autónomas españolas han sustituido el permiso de edificación por una simple comunicación previa si se trata de obras menores (modificaciones que no afecten el inmueble en su estructura, aspecto exterior, disposición interior o uso) o de escasa entidad técnica o impacto ${ }^{39}$. Asimismo, la recepción de obras ha sido reemplazada en algunos casos por declaración responsable o comunicación previa ${ }^{40}$, lo mismo que el inicio de actividades de comercio minorista ${ }^{41}$ o de comunicaciones electrónicas ${ }^{42}$ o audiovisuales ${ }^{43}$.

El esquema de autorización es también excesivo cuando procura evitar riesgos de actividades relativamente inocuas. Como explica Orlando, se pretende someter una actividad inocua a una intervención preventiva "solo

\footnotetext{
35 Por ejemplo, la sentencia en el caso Comisión v Reino de España (2008), apartado 57 , hizo alusión a las alternativas sugeridas en el Anexo de la Directiva 2004/67 del Consejo Europeo, de 2004, sobre seguridad en el suministro de gas natural.

36 Konle (1999), apartado $\mathrm{N}^{\circ} 47$.

37 Sanz de Lera (1995), apartado № 27. Ver también Bordessa y otros (1995), apartado № 27.

38 Comisión v Francia (2003).

39 VAquer 2013, 54.

40 FORTES 2013, 147.

41 Ibíd., 147.

42 Al respecto, la Directiva 2009/140/CE de 2006 justificó este cambio: "[e]l objeto es reducir progresivamente las normas 'ex ante' de carácter sectorial conforme avance el desarrollo de la competencia en los mercados para conseguir, en último término, que las comunicaciones electrónicas se rijan tan solo por las leyes de la competencia" (c. $5^{\circ}$ ).

43 FRANCO 2017, 47 y 51, respectivamente.
} 
porque casualmente podrían dar lugar a un hecho lesivo para la seguridad o al orden público" 44 .

Un segundo tipo de desproporción puede surgir de los requisitos exigibles para otorgar la autorización. Se produce, por ejemplo, cuando el grado de apreciación para autorizar no guarda relación con el nivel de riesgo que presenta la actividad ${ }^{45}$, como aquellos casos en que los criterios de licenciamiento para la adquisición de acciones en servicios privatizados son meramente indicativos o asociados a criterios de interés general indeterminados o indeterminables ${ }^{46}$.

Hay exceso también cuando la carga modal para la ejecución de una acción riesgosa afecta a otras independientes que no lo son, en una especie de carga "atada". Por ejemplo, el Tribunal Europeo declaró desproporcionada la posibilidad de no autorizar los derechos de voto o control en empresas energéticas de interés público, porque "se aplica a la totalidad de las decisiones que pueden someterse a votación de los accionistas, independientemente del riesgo que dichas decisiones pudieran entrañar para la seguridad del abastecimiento energético"47. Asimismo, declaró desproporcionado el sometimiento a autorización de todo complemento alimenticio que contuviera aminoácidos, por no distinguir entre riesgosos e inocuos ${ }^{48}$.

Similarmente, la Contraloría General de la República ha declarado que la norma restrictiva de una autorización "ha de aplicarse restrictivamente, siendo improcedente extenderla a otros servicios que no sean los taxativamente mencionados" ${ }^{49}$. Lo anterior es sin perjuicio de que, en caso de infracción, la clausura se extiende igualmente a todo el establecimiento ${ }^{50}$.

Una situación similar se produce cuando los requisitos para obtener la autorización se ordenan no solo a la prevención de riesgos cuya gravedad justifica un régimen autorizatorio sino también a otros que no lo ameritan. Por ejemplo, la jurisprudencia comunitaria consideró desproporcionado un esquema que condicionaba la autorización no solo al objetivo de seguridad del suministro mínimo de energía, sino también a la necesidad de mejorar la política energética ${ }^{51}$. Similar exceso provoca un modelo de licenciamiento de productos alimenticios que no distingue los componentes riesgosos para la salud ${ }^{52}$.

\footnotetext{
44 ORLANDO 1979, 186.

45 Comisión v Italia (2009), apartado N 52.

46 Comisión v Grecia (2012), apartados N76, Nº 78 y Nº 86.

47 Comisión v España (2008), apartado $N^{\circ} 47$.

48 Comisión v Alemania (2017), apartado Nº5.

49 Dictamen No 14.249 (2018); Dictamen N³4.124 (2002); Dictamen No 17.033 (2005); y Dictamen $\mathrm{N}^{\circ} 42.836$ (2015).

50 Corte Suprema. Rol N²0.969-2020, c. $9^{\circ}$.

51 Comisión v Reino de España (2008), apartado Nº 55.

52 Comisión v Dinamarca (2003), apartado N 55; Comisión v Francia (2010), apartado № 100.
} 
Por último, este tipo de desproporción puede darse en los pagos exigidos para otorgar la autorización. Al respecto, el Tribunal de Justicia de la Unión Europea declaró excesivo un mecanismo que supeditaba la autorización al pago de una tasa que cubría no solo la tramitación del procedimiento sino también los gastos de fiscalización del régimen regulatorio correspondiente ${ }^{53}$.

\section{Certeza e igualdad del régimen autorizatorio}

Otro punto crítico es el estándar de certeza respecto del nivel de riesgo que justifica la técnica autorizatoria, el cual suele ser más alto en Estados Unidos que en Europa. Específicamente, el espectro se mueve entre el principio preventivo de riesgo "racional y evidente previamente demostrado" vis-à-vis el principio precautorio o de cautela de peligros sobre los que persisten dudas científicas $^{54}$. El Tribunal de Justicia de la Unión Europea, por ejemplo, ha validado la autorización de alimentos cuando "subsisten dudas en el estado actual de la investigación científica acerca de determinadas sustancias" ${ }^{\prime 55}$. Las referencias del derecho chileno se acercan más al estándar precautorio europeo ${ }^{56}$.

El fundamento de la técnica autorizatoria determina también el grado de apreciación que exige su otorgamiento. El error en esta materia favorece vicios de incerteza jurídica, discriminación arbitraria y desviación de fin que también podrían estimular una declaración de inaplicabilidad o de inconstitucionalidad de la ley. En este sentido, la jurisprudencia comunitaria europea ha reiterado que la justificación del régimen autorizatorio debe ser objetiva, no discriminatoria y conocida de antemano ${ }^{57}$.

En materia de igualdad de trato, el Tribunal declaró discriminatoria la autorización previa de consultorios privados dentales por razones de calidad y cobertura, en circunstancias que consultorios "colectivos" análogos estaban exentos de dicho condicionamiento ${ }^{58}$.

\section{La relación jurídica autorizatoria}

La introducción de la potestad autorizatoria en un ámbito específico da origen a una relación jurídica entre el solicitante y el Estado, regida por un estatuto legal que constituye derechos distintos e independientes al derecho

53 Comisión v Reino Unido (2016), apartados №33 y N³4. Ver también, Germany GmbH y Arcor AG \& Co. KG v Alemania (2006), apartados $N^{\circ} 34$ y Nº 35.

54 En Chile, esta distinción ha sido formulada por Bermúdez 2014, 47, acogida por la Corte Suprema, por ejemplo, en Corte Suprema. Rol N³1.797-2018, c. $15^{\circ}$.

55 Comisión v Dinamarca (2003), apartados $\mathrm{N}^{\circ} 43^{\circ}, \mathrm{N}^{\circ} 49$ a $\mathrm{N}^{\circ} 52$. Ver también, Monsanto Agricoltura Italia y otros (2003), apartado No 113; Comisión v Francia (2010), apartados Nº 91 y No 92; Comisión v Alemania (2017), apartado Nº 60.

56 Corte Suprema. Rol N².138-2012, c. $4^{\circ}$. Ver también Corte Suprema. Rol No 11.485-2017, c. 34

57 Comisión v Holanda (2009), apartado N³5. Ver también Comisión v Francia (2002), apartado $N^{\circ}$ 50. Ver también caso Smits y Peerbooms (2001), apartado 90, y Comisión v Reino de España (2008), apartado $N^{\circ} 56$.

58 Comisión v Austria (2009), apartado N72. Para mayores antecedentes jurisprudenciales, Blanquer 2018, 240 y ss. 
cuyo ejercicio se pretende, así como gravámenes anejos al beneficio otorgado, como el de realizar la actividad en los términos autorizados ${ }^{59}$.

Esta distinción entre derecho ejercido y derechos que surgen del régimen autorizatorio es fundamental para evitar confusiones. A diferencia del primero, los segundos revisten la naturaleza de derechos personales, créditos, bienes incorporales ${ }^{60}$, reputados muebles, de carácter patrimonial, ex novo y de fuente legal. Solo son reclamables a la autoridad estatal que, por la sola disposición de la Constitución o de la ley, ha contraído la obligación correlativa de concretarlos o protegerlos. Estos derechos se refieren, principalmente, al otorgamiento y vigencia de la autorización, así como a las prerrogativas anejas ${ }^{61}$. Las principales consecuencias de esta distinción son dos.

Primero, la facultad de ejercer un derecho es distinta al derecho de ser autorizado para ello. La primera es inherente al derecho mismo, por tanto, solo podría ser limitada -sujeta a autorización u otras condiciones- pero jamás prohibida o privada absolutamente por el Estado de modo directo o indirecto, pues sería negar el derecho mismo. El segundo, en cambio, es constituido por el legislador para todo aquel que cumpla con los requisitos legales respectivos. Podría ser expropiado o limitado mediante una modificación de su estatuto normativo, sin perjuicio de las compensaciones a que haya lugar.

Segundo, la estabilidad de un acto autorizatorio ante la modificación o extinción sobreviniente de sus efectos o régimen jurídico no puede estar justificada en una suerte derecho de propiedad sobre el acto o sobre su normativa, que son de suyo inapropiables ${ }^{62}$. Antes bien, la supervivencia del acto solo podría estar basada en un crédito de vigencia que pudo haberse devengado como derecho bajo el estatuto anterior o en la confianza legítima en la inalterabilidad del acto por ausencia o auto-restricción de poderes específicos de modificación o extinción anticipada.

Al respecto, es preciso distinguir entre el derecho adquirido o confianza legítima de obtener la autorización; el derecho adquirido, mera expectativa o confianza legítima de vigencia de la autorización; y el derecho adquirido, confianza o mera expectativa de inmutabilidad de las condiciones habilitantes y cargas de la autorización.

\footnotetext{
59 Corte Suprema. Rol No $34.788-2016$, c. $34^{\circ}$.

60 Dictamen N ${ }^{\circ} 48.722$ (2012).

61 Así, por ejemplo, los actos autorizatorios constituyen el derecho ex lege de uso de bienes públicos en materia sanitaria, de gas, transporte y distribución de energía eléctrica, y telecomunicaciones. Art. 9 y 9 bis del D.F.L. N 382, Obras Públicas, de 1989; art. 12 inciso $1^{\circ}$ del D.F.L. $N^{\circ} 323$, Interior, de 1931; arts. 16, 24 inciso $3^{\circ}$ letra e) y 54 del D.F.L. $N^{\circ} 1$, Minería, 1982; art. 18 y 24 letra b) de la Ley $N^{\circ} 18.168$, de 1982.

62 Sentencia TC Rol No 467 (2006); Sentencia TC Rol No 1452 (2010); Sentencia TC Rol Nº 2069 (2011), y Sentencia TC Rol Nº 3208 (2016).
} 
1. Derecho adquirido o confianza legítima de obtención de la autorización

El titular de un derecho cuyo ejercicio conforme a la ley está sujeto a la obtención de una autorización adquiere el derecho personal o crédito para exigirla tan pronto haya cumplido con los requisitos legales y cargas procedimentales respectivos.

La omisión o negativa ilegal o arbitraria de otorgar la autorización a quien tiene el derecho adquirido a obtenerla conlleva un incumplimiento del deber legal correlativo que podría origen a la responsabilidad del Estado. Además, una vez devengado, la extinción de este derecho por acto estatal sobreviniente constituiría una privación de un derecho adquirido que, para ser justa, debe cumplir con los requisitos constitucionales de la expropiación (art. $19 \mathrm{~N}^{\circ}$ 24). De lo contrario, estaríamos en presencia de una desposesión antijurídica que sería equivalente, a su vez, a la privación "regulatoria" del derecho cuyo ejercicio se pretende.

Ahora bien, ¿qué ocurre si una ley o acto administrativo modifica los requisitos para obtener una autorización en perjuicio del solicitante una vez iniciado un procedimiento concreto? Al respecto, es preciso hacer las siguientes distinciones.

Si la normativa autorizatoria establece expresamente que los requisitos serán evaluados según las normas vigentes al momento de un acto trámite determinado ( $v$. gr. solicitud) ${ }^{63}$, la modificación sobreviniente de las condiciones no debería afectar el derecho adquirido del solicitante a obtener la autorización según los términos originales, a menos que medie una expropiación del mismo en los términos señalados anteriormente.

Un ejemplo de lo anterior es el precepto normativo en virtud del cual un anteproyecto aprobado por la Dirección de Obras Municipales (DOM), que sirve de acto trámite ${ }^{64}$ para la obtención de un permiso de edificación por el mismo órgano, mantiene su vigencia respecto de todas las normas urbanísticas consideradas en aquel y con las que se hubiere aprobado ${ }^{65}$.

Esta solución fue puesta a prueba en un caso donde, estando pendiente la aprobación de un anteproyecto de edificación sobre un terreno no afecto a declaración de utilidad pública, una ley declaró dicha afectación para todo inmueble de ese tipo que no haya sido objeto de un anteproyecto aprobado o de un permiso otorgado. Pese a que, en consecuencia, el terreno en cuestión no podía acogerse a esta excepción legal, la Municipalidad aprobó igualmente el anteproyecto y otorgó el permiso de edificación y las recepciones correspondientes. Ante el reclamo de ilegalidad de estas últimas actua-

\footnotetext{
${ }_{63}$ Este es el caso, por ejemplo, de la solicitud de permisos de edificación según el art. 116 de la Ley General de Urbanismo y Construcciones, de 1976, y de los arts. 1.1.3. y 1.4.7 de la Ordenanza General de la Ley General de Urbanismo y Construcciones, de 1992. Así lo confirma también Corte Suprema. Rol No 50.662-2020, c. $6^{\circ}$.

${ }^{64}$ Corte Suprema. Rol No29.945-2018, c. $11^{\circ}$.

65 Art. 116 de la Ley General de Urbanismo y Construcciones, de 1976.
} 
ciones, el Tribunal Constitucional declaró la inaplicabilidad de la ley porque constituía "una restricción posterior al ejercicio legítimo de derechos existentes reclamados en forma oportuna. En otras palabras, se trata de una regulación ex post con un efecto ex ante"66.

Asimismo, una ley o acto administrativo que altere los requisitos urbanísticos de quien ha obtenido un permiso de edificación es expropiatoria del derecho adquirido a obtener la recepción de obras o autorización de primer uso o habitación según "las normas urbanísticas aplicables a la obra, conforme al permiso otorgado"67.

En cambio, si la normativa autorizatoria no provee solución expresa al cambio sobreviniente de requisitos, el solicitante solo goza de la expectativa legítima de que será autorizado según las condiciones vigentes al momento de su solicitud. Esta confianza podría verse frustrada por la alteración repentina de las condiciones, lo que obligaría al Estado a seguir la metodología de protección de expectativas.

En el plano práctico, según explica la doctrina de la confianza legítima68, la expectativa de obtención de la autorización puede ser protegida mediante tres mecanismos según la ponderación entre el interés público que amerita el cambio normativo y el interés del particular: a) evaluar y entregar la autorización según los requisitos originales por resultar inocuo al interés público subyacente al cambio. Esta solución solo podría ser dispuesta por el legislador, por el órgano administrativo que goza de discrecionalidad para decidir la aplicación de la norma en el tiempo, o por el juez por vía de control de esa discrecionalidad o mediante la inaplicabilidad de la ley previa declaración del Tribunal Constitucional; b) incorporar una norma o aplicar un criterio discrecional de transitoriedad que impida la vigencia brusca del cambio normativo; y c) compensación del daño patrimonial causado por frustración brusca o intempestiva de la confianza legítima.

Un ejemplo sería el cambio normativo posterior a la emisión de un certificado de informaciones previas sobre un inmueble. Dado que este certificado no es un acto trámite del permiso de obras, el solicitante no goza de derecho adquirido a la obtención del permiso en los términos del certificado. Antes bien, esa certificación "(...) mantendrá su validez y vigencia mientras no se publiquen en el Diario Oficial las modificaciones a las normas urbanísticas (...)" (art. 116 inciso $2^{\circ}$ ). Sin embargo, una modificación brusca y perjudicial de tales normas ciertamente afectaría la confianza legítima en obtener el permiso según lo previsto en el certificado.

\footnotetext{
66 Sentencia TC Rol N 5.172 (2018), c. $13^{\circ}$. Esta sentencia marcó un cambio de jurisprudencia en relación con Sentencia TC Rol N³.208 (2016), y Sentencia TC Rol Nº 3.250 (2016).

67 Art. 144 inciso $4^{\circ}$ de la Ley General de Urbanismo y Construcciones, de 1976. Cfr. VIÑUELA 2005, 107 y ss.

68 En el ámbito autorizatorio, puede verse lo sostenido por LAGUNA DE PAZ 2006, 287-290; FRANCO 2017, 372 y 398 y ss. Ver también PHILLIPS 2020, 174 y ss.
} 
Un caso similar se dio con la modificación de los requisitos legales para obtener una autorización sanitaria durante la tramitación del procedimiento respectivo y en ausencia de norma sobre cambio normativo. El ente contralor tomó razón del acto que evaluó los requisitos según la norma antigua en razón de la confianza legítima del solicitante ${ }^{69}$. En otro caso, la Corte Suprema declaró que una autorización de traspaso de patentes municipales se regía por la normativa antigua y no por la sobreviniente a la solicitud por aplicación del principio de confianza legítima ${ }^{70}$.

2. Derecho adquirido, confianza legítima o mera expectativa de vigencia de la autorización

Una vez otorgada la autorización, la doctrina sobre sus efectos o vigencia en el tiempo no ha sido uniforme porque se debate entre los derechos adquiridos $^{71}$ y las meras expectativas de actos "libremente revocables"72. En este sentido, la revocación o decaimiento del acto autorizatorio por razones de mérito, oportunidad o conveniencia sería expropiatoria para la primera tesis y jurídicamente irrelevante para la segunda. Pensamos, en cambio, que no es posible subsumir los efectos del acto en una sola categoría jurídica porque todo depende de los intereses o derechos garantizados por el régimen legal de cada autorización. La autorización no es, por así decirlo, esencialmente estable o precaria, lo que nos permite criticar la jurisprudencia que sostiene lo contrario ${ }^{73}$.

Dependiendo de los modos de extinción del acto regulados en la ley, la estabilidad de la autorización halla sustento en un derecho adquirido, en una confianza protegida o en una mera expectativa.

La conclusión anterior se opone, en particular, a la doctrina dominante que desconoce el derecho adquirido a la estabilidad del acto autorizatorio debido a que este solo permitiría el ejercicio de un derecho preexistente ${ }^{74}$. En este sentido, a diferencia de la concesión, el acto autorizatorio no conferiría un derecho ex novo alguno al solicitante ${ }^{75}$.

No compartimos estos argumentos. En nuestro parecer, el efecto legalizante no guarda relación alguna con los efectos del acto autorizatorio en el tiempo, que dependen más bien de sus causales de extinción. Veamos.

\section{a) Derecho adquirido de vigencia de la autorización}

Una autorización válida genera el derecho personal o crédito de exigir su estabilidad al Estado cuando su vigencia depende de un plazo o condición

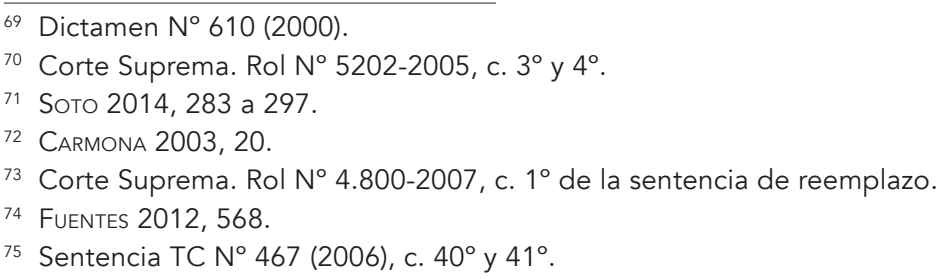


específica distinta de su revocación o decaimiento por actos legislativos o administrativos de interés público. En otras palabras, no existe una potestad estatal de término anticipado de la autorización que no sea la declaración de caducidad por incumplimiento de las obligaciones del titular; o, si esa atribución existe, ha sido mal ejercida u objeto de compromiso formal y legal, judicial o extrajudicial, de no ser ejercida durante un tiempo. Un ejemplo de acto autorizatorio estable es el permiso extraordinario ${ }^{76}$ o la licencia transable de pesca ${ }^{77}$ y el permiso de edificación respecto de potestades distintas a la declaración de monumento nacional que veremos a continuación ${ }^{78}$.

La potestad revocatoria prevista en la Ley $N^{\circ} 19.880$ no vale como poder extintivo en estos casos porque no puede ser ejercida respecto de "actos declarativos o creadores de derechos adquiridos legítimamente" (art. 61 letra a). Esta afirmación admite el contraargumento circular de que, según nuestro propio criterio, ningún derecho de vigencia podría ser adquirido si existe una potestad legal de revocación general. Sin embargo, semejante interpretación llevaría ineludiblemente a sostener que, a partir de la introducción de ese poder genérico, ningún acto administrativo podría producir derechos adquiridos, lo que vuelve superfluo el límite del precepto. Dado que el sentido en que una norma puede producir algún efecto debe preferirse a aquel en que no sea capaz de producir efecto alguno, pensamos que la potestad revocatoria que excluye el derecho de vigencia debe ser distinta a la prevista en la Ley $N^{\circ} 19.880$.

Siguiendo con nuestro razonamiento, si una ley sobreviniente pusiera término a una autorización de vigencia definida, o habilitara a la Administración para revocarla o provocar su decaimiento, ¿qué efecto jurídico tendría semejante actuación? La Corte Suprema ha declarado de modo tautológico en materia urbanística que sería expropiatoria del derecho de propiedad sobre el ejercicio del derecho de propiedad sobre un inmueble ${ }^{79}$. Sin embargo, en nuestra opinión, lo verdaderamente expropiado en esa hipótesis es el derecho legal o crédito de vigencia autorizatoria adquirido por el solicitante respecto del Estado. El ejercicio del derecho sería objeto, a lo más, de una expropiación indirecta o "regulatoria"80. Pensemos en la siguiente imagen: ¿qué pasaría si se ordenara bajar la báscula de la Tower Bridge de Londres minutos antes del tiempo para ejercer el derecho de tránsito fluvial por razones de interés público? ¿No habría acaso una privación de un derecho adquirido exigible al órgano autorizante?

\footnotetext{
76 Art. 2 N 27 del D.S. N 430, Ministerio de Economía, Fomento y Reconstrucción, de 1992.

77 Íbid., arts. 37 y 39. Vid. Mensaje de S.E. el Presidente de la República con el que se inicia un proyecto de ley que establece el Régimen Especial de Pesca, Boletín 2274-03, de 1998, 4 a 5.

78 Soto 2000, 1-9; Figueroa y Figueroa 2006, 174-175; Díaz de Valdés y Enteiche 2015, 254 y ss. Corte Suprema. Rol N³3.611-1996 y Dictamen N 12.664 (2006).

79 Corte Suprema. Rol N 4.800-2007, c. $2^{\circ}$ de la sentencia de reemplazo.

80 Para una profundización del concepto y de la posibilidad de aplicarlo en Chile, véase GuILOFF 2018, 621-648.
} 
Para ser justa, por tanto, esa privación debería regirse por los requisitos que la Constitución establece al efecto: causal de interés público, potestad legal y debida compensación (art. $19 \mathrm{~N}^{\circ} 24$ ). El incumplimiento de estos requisitos podría dar origen a la responsabilidad del Estado. Además, la extinción anticipada del acto estable por esta vía solo podría concretarse antes de la consumación de la actividad autorizada, pues de lo contrario estaría extinto por cumplimiento de su objeto ${ }^{81}$.

\section{b) Mera expectativa o precariedad de vigencia de la autorización}

En cambio, una autorización válida, cuya vigencia está condicionada ab initio o hace tiempo -no hay, por tanto, confianza legítima- al poder extintivo legal o administrativo por razones de interés público diferentes a la caducidad, solo genera una mera expectativa de estabilidad o título precario respecto de dichos poderes. La sola previsión legal de que ese acto puede ser extinguido por leyes o decisiones administrativas específicos inhibe un derecho adquirido a su supervivencia más allá de estos actos. Este sería el caso, por ejemplo, de las autorizaciones pesqueras ${ }^{82}$ y de los permisos de edificación con respecto a la eventual declaración de monumento protegido por la Ley $\mathrm{N}^{\circ} 17.288^{83}$.

Para ser válida, esta posibilidad de extinción debe ser razonablemente "previsible" con respecto al acto en particular en razón de la especificidad, densidad normativa, O "capa regulatoria" 84 en que se encuentra la norma que la prevé. Esto significa que la precariedad no puede estar fundada en poderes legislativos o administrativos genéricos o extranei cuya aplicabilidad resulte inesperada en el ámbito regulatorio ad hoc. Semejante "paracaidismo" potestativo solo podría dar paso a un vicio de competencia, descoordinación o a la protección de la confianza legítima en su inaplicabilidad.

De lo anterior se desprende que la precariedad es siempre una cualidad relativa del acto autorizatorio, pues solo se predica respecto de los poderes específicos actuales que podrían revocarlo o hacerlo decaer. En otras palabras, una autorización es siempre precaria respecto de esos poderes y estable respecto de todos los demás. Dependiendo de si el acto autorizatorio es de vigencia definida o indefinida, esa estabilidad estará protegida por un derecho adquirido o por una confianza legítima respectivamente.

Por ejemplo, el titular de una autorización pesquera en etapa de plena explotación adquiere el derecho de estabilidad hasta el fin de dicho régimen por declaración de pesquería en recuperación ${ }^{85}$, a menos que incurra en una

\footnotetext{
81 Cordero Quinzácara 2020, 359-360.

82 Art. 2 N 10 y art. 15 de D.S. N 430, Ministerio de Economía, Fomento y Reconstrucción, de 1992. FUENTES 2012, 555 y ss.

83 Sentencia TC Rol No 1199 (2012).

${ }^{84}$ Esta expresión ha sido utilizada por el profesor Jaime Phillips Letelier en su defensa de tesis doctoral y conversación sobre el tema con el suscrito.

${ }^{85}$ Art. 39 inciso $2^{\circ}$ del D.S. N 430, Ministerio de Economía, Fomento y Reconstrucción, de 1992.
} 
causal de caducidad ${ }^{86}$. Se ha sostenido que esta autorización no crea derechos subjetivos en favor de sus titulares porque su revalorización económica en ese período corresponde únicamente a un "privilegio fáctico"87. Si bien esta última afirmación es correcta, no sirve para descartar el derecho legal a la vigencia de la autorización durante dicho régimen, oponible no solo a la Administración sino también al poder legislativo.

\section{c) Confianza legítima de vigencia de la autorización}

Sin perjuicio de lo anterior, una autorización precaria podría dar origen a una expectativa de continuidad jurídicamente protegida en las hipótesis siguientes no taxativas.

Primero, si la relación autorizatoria es de tracto sucesivo y ha sido renovada en ocasiones anteriores en circunstancias similares.

Segundo, en caso de compromiso estatal informal o extra legal confiable de no ejercer la potestad extintiva ad hoc durante un período de tiempo específico o de modo brusco.

Tercero, ante la supervivencia prolongada de la autorización bajo un régimen legal que puso término a la potestad autorizatoria. Este fue el caso, por ejemplo, de las autorizaciones indefinidas para el muellaje en el Puerto de Arica, que continuaron vigentes por varios años pese a que una ley posterior dispuso la estatización y entrega en concesión de dicha actividad ${ }^{88}$. Dado que la ley sobreviniente tenía varios años de vigencia, no era posible alegar confianza legítima en la estabilidad del régimen anterior pero sí en que la extinción de las autorizaciones vigentes sería transitoria o compensada. Entonces, si bien compartimos el parecer de la Corte Suprema ${ }^{89}$ y del Tribunal Constitucional ${ }^{90}$ en cuanto a que no existía un derecho adquirido a la estabilidad de esas autorizaciones, nos parece que erraron al no reconocer y proteger la confianza legítima de sus titulares ante una licitación intempestiva.

Cuarto, si el mérito, oportunidad o conveniencia que justificó la extinción de una autorización válida existía y debía ser conocido por el Estado al momento de su otorgamiento a un sujeto de buena fe, esto es, a quien no haya infringido culposamente el deber legal de saber e informar tales circunstancias a la autoridad. La extinción total o parcial del acto autorizatorio en este caso no corresponde verdaderamente a una revocación o decaimiento por hecho sobreviniente sino a una invalidación encubierta por error, negligencia o falta de coordinación interna del Estado. La base de confianza legítima en la estabilidad del acto dependerá de si el destinatario conocía las

\footnotetext{
86 Ibíd., art. 23.

87 MonTt 2010, 26.

88 Para una explicación más detallada de esta figura, introducida por la Ley N 19.542, de 1997, véase ArancibIA, 2019, 360-362.

89 Corte Suprema. Rol No 1.428-2007. Ver también Corte Suprema. Rol N 1.469-1999.

90 Sentencia TC Rol No 467 (2006).
} 
circunstancias extintivas ex tunc. Si la respuesta es positiva, su expectativa legítima está basada en que el Estado, sabiendo o debiendo saber tal situación impediente de la actividad, decidió autorizarla igualmente. En cambio, si le eran desconocidas, la base de confianza halla sustento en la presunción de validez del acto revocado por un vicio de origen, circunstancia que deberá acreditar.

Un ejemplo de lo anterior sería la declaratoria de monumento histórico de un inmueble una vez aprobado el anteproyecto de edificación, y a solo semanas de haberse otorgado un permiso municipal para su demolición, como ocurrió en el caso Villa San Luis de Las Condes ${ }^{91}$. El recurso de protección, interpuesto por una empresa de construcción que había adquirido el inmueble de otra que lo había comprado al Fisco expresamente para fines constructivos, fue rechazado por razones procesales ajenas al fondo del asunto. Sin embargo, pensamos que la solución sustantiva del caso habría exigido el resguardo de la confianza legítima en la eficacia del permiso sobre la base de tres actos estatales contemporáneos a los hechos que ameritaron la declaración de monumento histórico: la venta del inmueble nada menos que a una empresa constructora, la aprobación municipal del anteproyecto y el permiso municipal de demolición.

A la luz de este caso, parece ser que la frustración de expectativas legítimas se produce por descoordinaciones entre organismos de un mismo Estado. Estas deberían ser evitadas, por ejemplo, mediante la solución legal de decisiones contradictorias, o solicitando un informe al órgano que podría ver comprometida sus competencias con el acto terminal ajeno. De lo contrario, la inconsistencia decisional resulta imputable al mismo Estado en razón del carácter unitario de la relación jurídica pública92.

Otra hipótesis de confianza legítima sería la de una autorización indefinida en el tiempo, es decir, no supeditada a poderes extintivos específicos que sean diferentes a la declaración de caducidad. Un acto de este tipo no es apto para adquirir un derecho de estabilidad porque carece de finitud mínima o de perpetuidad necesaria para exigir su vigencia en el tiempo. Sin embargo, su titular goza de una expectativa de continuidad protegida, basada en que el estatuto legal aplicable no prevé causales de extinción específicas por actos del legislador o del poder ejecutivo. Esta confianza se vería frustrada por cualquier extinción repentina de la autorización producto de una ley sobreviniente.

Por último, el beneficiario de buena fe de un permiso tiene la confianza legítima de su continuidad pese a adolecer de vicios de legalidad ab initio. Por tanto, la eventual invalidación o nulidad del acto obliga a proteger esta expec-

91 Corte Suprema. Rol No 8.136-2018.

92 Arancibia 2017, 10-12. Corte Suprema. Rol N³1.594-2018, c. $4^{\circ}$. 
tativa o "situación jurídica consolidada", en nomenclatura contralora93, según los mecanismos de resguardo que ofrece la aplicación de este principio.

\section{Derecho adquirido, mera expectativa o confianza legítima de inmutabilidad de las cargas de la autorización}

¿Existe el derecho a la inmutabilidad de las condiciones habilitantes o cargas públicas anejas a la autorización? En nuestra opinión, por regla general, no. Tales cargas o deberes constituyen meras limitaciones al ejercicio del derecho cuya modificación in peius -por ley o potestas variandi administrativa- no es privativa de derechos. Así se desprende también de la Ley sobre Efecto Retroactivo de las Leyes, que si bien no regula en forma específica el caso de los actos administrativos ${ }^{94}$, suele someter los derechos a la ley vigente al momento de su nacimiento, y las obligaciones y condiciones de ejercicio a la normativa posterior ${ }^{95}$.

La excepción está dada, sin embargo, por aquellos casos en que el legislador o el órgano administrativo han comprometido expresa o explícitamente la inmutabilidad de tales deberes o condiciones, lo que constituye un deber de inactividad o negativo cuyo correlato es un derecho adquirido del sujeto autorizado. Este sería el caso, como vimos, de las obligaciones que surgen de los permisos de edificación, respecto de las cuales el legislador ha comprometido su intangibilidad.

Sin perjuicio de lo anterior, de no existir dicho compromiso expreso o de ser ilegal, la modificación sería conforme a derecho en la medida que resguarde, inter alia, la confianza legítima del titular de la autorización en la estabilidad de dicho acto.

Un buen ejemplo sobre esta materia es la Ley $N^{\circ} 21.134$, que prohibió la extracción de la especie marina jibia mediante artes o aparejos distintos a la potera o línea de mano a partir de seis meses de la publicación de la norma. Esta ley afectó las autorizaciones vigentes que habilitaban la extracción de la especie mediante pesca de arrastre. La pregunta entonces es si la prohibición afectó un derecho adquirido, una confianza legítima o una mera expectativa de continuar utilizando dicho arte de pesca.

En nuestra opinión, esta ley no proscribió sino que condicionó el ejercicio del derecho de pesca de la jibia durante el período de plena explotación; por tanto, no existe un problema de vigencia sino de cargas legales accesorias de la autorización, sobre las que no existe un derecho de inmutabilidad en el caso concreto. Al contrario, la Ley $N^{\circ} 18.892$ establece que la actividad pesquera autorizada debe realizarse "conforme con la normativa vigente" (art. 15). Sin embargo, respecto de las autorizaciones vigentes, la modifica-

\footnotetext{
${ }_{93}$ Por ejemplo, Dictamen No5.625 (2013), Dictamen N53.290 (2004), Dictamen N³5.681 (2009).

94 PHILLIPS 2020, 130-134.

${ }_{95}$ Cfr. arts. 8, 12 y 16 de la Ley sobre Efecto Retroactivo de las Leyes de 1861 (s/n).
} 
ción legal podría frustrar igualmente la confianza legítima en la estabilidad del régimen anterior en caso de que los seis meses de vacatio legis previstos hayan sido insuficientes para la debida adaptación de los sujetos concerni$\operatorname{dos}^{96}$. Este criterio sería también aplicable a la modificación de una resolución de calificación ambiental (RCA) ${ }^{97}$.

\section{Especies del genus autorizatorio}

Es importante consignar que el título que legaliza el ejercicio de un derecho solo reviste una naturaleza autorizatoria cuando consiste en un acto administrativo que declara o certifica el cumplimiento de los requisitos habilitantes. En este sentido, la autorización es solamente una especie dentro del género modal que permite ejercer un derecho secundum legem. De ahí que no corresponde atribuir un carácter autorizatorio a cualquier hecho.

Sin perjuicio de lo anterior, dado que la autorización supone necesariamente la dictación de un acto administrativo, el genus autorizatorio admite denominaciones y técnicas varias. En este sentido, en la medida que legalicen la actividad, podemos incluir en este género a las siguientes especies de actos administrativos: permiso ${ }^{98}$, patente ${ }^{99}$, certificado ${ }^{100}$, aprobación ${ }^{101}$, incorporación en nómina ${ }^{102}$, registro ${ }^{103}$ o catastro público, acreditación ${ }^{104}$, ho-

\footnotetext{
96 El Tribunal Constitucional rechazó la inaplicabilidad de la norma prohibitiva en Sentencia Rol $N^{\circ}$ 8.614-2020, básicamente porque rige in actum, no existe un derecho de propiedad sobre normas, y no existe privación del derecho a pescar. Si bien compartimos estas declaraciones, no compartimos el fallo por haber omitido lo verdaderamente relevante del conflicto, esto es, si la frustración de expectativas por el cambio legislativo era o no conforme a la Constitución en razón del período de adaptación estipulado.

97 Dictamen No 20.477 (2003); Dictamen N³4.021 (2003). VIÑUELA 2005, 109 y ss.

98 Permiso de edificación municipal, art. 166 del D.F.L. N 458, Vivienda y Urbanismo, de 1976. Sentencia TC Rol No 437 (2005); permiso de circulación vehicular, arts. 12 y ss. del D.L. N 3.063, de 1979.

99 Patente municipal para inicio de giro o actividad, arts. 23 y ss. del D.L. N 3.063, de 1979.

100 Certificado de homologación de vehículos motorizados. Art. 2 Nº 25 D.F.L. N ํo 1, Ministerio de Transportes y Telecomunicaciones, de 2009.

101 La aprobación de operaciones de concentración económica a cargo de la Fiscalía Nacional Económica (art. 49 y ss. del D.F.L. N 1, Ministerio de Economía, Fomento y Reconstrucción, de 2005).

102 Nombramiento en Nómina de Liquidadores (art. 30 de la Ley N²0.720, de 2014). Sentencia TC Rol No 1.413 (2009), c. $10^{\circ}$.

103 Inscripción de vehículos en el Registro Nacional de Servicios de Transporte de Pasajeros. Artículo 3 inciso $7^{\circ}$ de la Ley $N^{\circ} 18.696$, de 1988, en relación con los artículos 9 y 19 de la Ley No 19.040, de 1991, y artículo 3 del D.S. N²12, Transportes y Telecomunicaciones, 1992.

104 Arts. 23 y ss. del D.L. N 3.063, de 1979. Ver también Corte Suprema. Rol N².551-2018, c. $5^{\circ}$. Ver también Corte Suprema. Rol N 434-2015, Corte Suprema. Rol No21.183-2014, Corte Suprema. Rol N552-2013 y Corte Suprema. Rol N58.992-2016.
} 
mologación ${ }^{105}$, calificación ${ }^{106}$, visado ${ }^{107}$, padrón ${ }^{108}$, licencia ${ }^{109}$, y reconocimiento oficial ${ }^{110}$, entre otros.

La naturaleza autorizatoria de estos actos administrativos estriba en que permiten el ejercicio del derecho conforme a la ley, razón por la cual los homónimos que carecen de ese efecto no son autorizatorios. Es el caso, por ejemplo, del registro de organismos autorizados para labores de certificación, inspección, ensayo o control de productos eléctricos, de gas o de combustión ${ }^{111}$, cuya finalidad es meramente catastral respecto de entidades ya autorizadas.

\section{Fronteras del genus autorizatorio}

La autorización administrativa comparte elementos similares con otros títulos de legalización o potestades administrativas que es preciso identificar para evitar confusiones en el régimen jurídico aplicable. Nos referimos, específicamente, a las legalizaciones ope legis, concesiones y regulaciones. La presencia de elementos comunes en estas técnicas configura una verdadera triple frontera para la autorización que ha sido fuente de malos entendidos para los operadores jurídicos.

\section{Frontera autorización-legalización ope legis}

En particular, los hechos o actos que legalizan el ejercicio de un derecho ope legis, esto es, por el solo ministerio de la ley, sin necesidad de un acto administrativo que así lo declare o certifique, no revisten una naturaleza autorizatoria. Entre estos figuran los actos privados de comunicación previa a realizar la actividad ${ }^{112}$, la declaración responsable de cumplimiento de la normativa ${ }^{113}$, y la obtención de certificados favorables de entidades privadas acreditadas pero no concesionarias del Estado ${ }^{114}$, como la etiqueta de consumo

\footnotetext{
105 Homologación de máquinas de juego. Art. 29 y ss. de la Ley N 19.995, de 2005.

106 Resolución de Calificación Ambiental, Ley N 19.300, de 1994, Título II, Párrafo $2^{\circ}$.

107 Art. 5 del D.L. 1.094, de 1975.

108 Padrón o permiso de circulación vehicular (art. 2 Nº 35 del D.F.L. N 1, Ministerio de Transportes y Telecomunicaciones, de 2009)

109 Licencia de conductor, art. 2 del D.F.L. N 1, Ministerio de Transportes y Telecomunicaciones, de 2009.

110 Reconocimiento oficial de establecimiento educacional (arts. 45 y ss. DFL N ${ }^{\circ} 2$, Ministerio de Educación, de 2010). Sentencia TC Rol No 1.363 (2009), c. 16 , y Sentencia TC Rol N² 2.731 (2014), c. $11^{\circ}$.

111 Art. $3 \mathrm{~N}^{\circ} 14$ inciso $3^{\circ}$ de la Ley $\mathrm{N}^{\circ} 18.410$, de 1985.

112 Esta figura fue introducida en la Unión Europea por la Directiva 2006/123/CE del Parlamento Europeo y del Consejo, de 2006. Cfr. Blanquer 2018, 267 y ss.

113 ĺbid.

114 Por ejemplo, el "certificado de aprobación a los productos, máquinas, instrumentos, equipos, artefactos, aparatos y materiales eléctricos, de gas, combustibles líquidos, y los que utilicen leña y otros productos dendroenergéticos como medio de combustión". Art. $3 \mathrm{~N}^{\circ} 14$ de la Ley $N^{\circ} 18.410$, de 1985.
} 
energético de equipos y máquinas, entre otros ${ }^{115}$. En todos estos casos, la intervención administrativa, de existir, operará ex post y no será habilitante ${ }^{116}$.

\section{Frontera autorización-concesión}

Formular una distinción clara entre autorización y concesión es necesaria debido a su confusión en contextos normativos variados. Entendemos la concesión como un acto estatal unilateral que determina la constitución de un bien o gravamen de titularidad pública a un particular con fines de fomento, policía, servicio o empresa del Estado ${ }^{117}$. La confusión con la autorización proviene, precisamente, de su objeto habilitante de derechos o labores de un particular.

Esta equivocación se observa, primeramente, en actividades despublificadas o privatizadas sujetas a regulación que en su momento fueron estatales y concesionadas, pues la inercia del régimen anterior ha llevado al legislador a cometer errores terminológicos. Un ejemplo es la habilitación administrativa en materia distribución privada de energía eléctrica ${ }^{118}$, agua potable ${ }^{119}$ y gas $^{120}$, que el legislador denomina "concesión" pese a que se trata de actos autorizatorios $^{121}$.

Un problema similar surge en el ámbito de los bienes nacionales, fiscales o municipales, cuya publicatio puede dar pie a la idea errada de que cualquier habilitación especial a particulares es de naturaleza concesional, en circunstancias de que también puede ser autorizatoria. Por ejemplo, los peajes en puentes, caminos y túneles ${ }^{122}$, así como los permisos de acceso preferente a vías públicas de tránsito restringido ${ }^{123}$, no corresponden a concesiones sino a autorizaciones para ejercer el derecho preexistente de uso de bien nacional de uso público ${ }^{124}$.

La confusión ocurre también en sentido contrario, al calificar como autorización un acto materialmente concesional. Así, parte de la doctrina ${ }^{125}$ y de la jurisprudencia constitucional ${ }^{126}$ conciben la habilitación de particulares para labores de muellaje en los puertos chilenos como una autorización. Empero, la figura obedecería más bien a la de una concesión obligatoria, pues la propia

\footnotetext{
115 Art. 4 del D.L. N².224, de 1978.

116 Franco 2017, 217 y 222.

117 ARANCIBIA 2019, 329 y ss.

118 D.F.L. N 4, Ministerio de Economía, Fomento y Reconstrucción, de 2008, arts. 2 y 3.

119 Art. 4 y ss. de la D.F.L. N³82, Obras Públicas, de 1988.

120 Art. 1 del D.F.L. N ${ }^{\circ} 323$, Interior, de 1931.

121 Soto 2012, 569. También, Mendoza 1998, 707 a 720. En España, Franco 2017, 35 y ss.

122 Arts. 29 y 75 del D.F.L. N 850, Obras Públicas, de 1998. Ver Dictamen N 17.393 (1999), Dictamen $\mathrm{N}^{\circ} 23.701$ (1999), y Dictamen $\mathrm{N}^{\circ} 60.482$ (2013).

123 Art. 3 inciso $2^{\circ}$ de la Ley $N^{\circ} 18.696$, de 1988.

124 Art. 589 del Código Civil.

125 Aróstica 2001, 62 y 63.

126 Sentencia TC Rol № 467 (2006), considerandos 39 y ss.
} 
Ley $N^{\circ} 19.542$ califica tales servicios como "comprendidos dentro del objeto de las empresas [estatales]" (art. 5), solo que ordena su prestación a través de particulares. Conforme a este criterio, la Corte Suprema sostuvo que dicha potestad era de naturaleza concesional ${ }^{127}$.

Otro ejemplo sería el uso de las expresiones "permiso", "licencia" o "autorización" para referirse a concesiones precarias, de menor entidad o fin estrictamente privado, como en materia municipal ${ }^{128}$, de vialidad ${ }^{129}$, radioeléctrica ${ }^{130}$, de transporte y distribución de energía eléctrica ${ }^{131}$, de acuicultura $^{132}$, y de bienes fiscales ${ }^{133}$.

Para solucionar estos desaciertos, la doctrina ha procurado distinguir ambas potestades en razón de sus atributos. Sin embargo, en nuestra opinión, las propuestas continúan siendo insatisfactorias o insuficientes. Los referentes indiscutidos en esta materia son Mayer ${ }^{134}$ en Alemania y Raneletti ${ }^{135}$ en Italia, para quienes la autorización es un acto de comprobación o declarativo que tiene la aptitud de levantar una barrera para el ejercicio de un derecho preexistente. Se diferenciaría así de la concesión, que constituye un derecho y cargas respecto del concesionario ${ }^{136}$.

Esta distinción, seguida casi de forma unánime por la doctrina ${ }^{137}$ y la jurisprudencia ${ }^{138}$, nos parece errada porque confunde las funciones que le corresponden al legislador y al órgano administrativo en el régimen autorizatorio y concesional. La constitución de relaciones jurídicas en el derecho administrativo es de fuente legal, razón por la cual los actos administrativos solo pueden tener un objeto declarativo o condenatorio respecto de los derechos y obligaciones que surgen de estas.

En este sentido, tanto la autorización como la concesión son actos administrativos de objeto declarativo que producen un efecto constitutivo ope legis. Declaran que un sujeto concreto ha adquirido una posición, calidad, estatus o estado jurídico de la que surge una relación jurídica de naturaleza legal con el Estado. El que la Administración declare y el legislador constituya demuestra que la relación jurídica del particular es con el Estado y no solo

\footnotetext{
127 Corte Suprema. Rol No 1.469-1999.

128 Art. 36 de D.F.L. N ${ }^{\circ}$ 1, Ministerio del Interior, de 2006 y art. 26 inciso cuarto del D.F.L. N 850, Obras Públicas, de 1998. Sentencia TC Rol N 1991 (2012).

129 Art. 14 del D.F.L. N² 206, de 1960.

130 Arts. 2, 8 y 9 de la Ley $N^{\circ} 18.168$, de 1982.

131 Art. $2 \mathrm{~N}^{\circ} 3$ y 12 del D.F.L. N 4, Ministerio de Economía, Fomento y Reconstrucción, de 2007.

132 Art. 3 del D.F.L. N 340 , de 1960.

133 Art. 19 inciso $2^{\circ}$ del D.L. N 1.939 , de 1977.

134 Para seguir la terminología acuñada por MAYER 1982, 59 y ss.

135 Ranelletti, 1894.

136 GonZÁlez 1965, 34.

137 Real Academia Española, 2019, 232; García de Enterría y Fernández 2017, 161-164. En Chile, véase Cordero Vega 2015, 256; Bermúdez 2014, 145 y 323.

138 En Chile véase Sentencia TC Rol Nº 467 (2006), c. $41^{\circ}$.
} 
con uno de sus órganos. En otras palabras, la declaración de un sujeto como "autorizado" o "concesionario" es apta para crear o constituir derechos u obligaciones legales específicos eventualmente precisados por actos administrativos. Por tanto, autorización y concesión son tan declarativas como constitutivas.

Otra posible diferencia sería el carácter unilateral de la autorización versus el contractual de la concesión ${ }^{139}$. Sin embargo, esta distinción también sería errónea. Primero, si la bilateralidad radica en la existencia de obligaciones recíprocas entre el Estado -que respeta la concesión-y el particular-que cumple con las obligaciones anejas a la misma-, semejante reciprocidad también podría concurrir en un acto autorizatorio sujeto a modalidades. Por otro lado, si la bilateralidad se refiere al número de voluntades que concurren al perfeccionamiento del acto o surgimiento de la relación jurídica pública, tampoco correspondería aplicarla a la figura concesional, pues esta consiste en un acto jurídico unilateral de efectos bilaterales sujeto a la condición suspensiva de aceptación o rechazo por parte del particular ${ }^{140}$.

Precedentes adicionales han procurado diferenciar ambos institutos según el inicio del procedimiento, que obedecería a una licitación en el caso de la concesión y a una solicitud en el caso de la autorización. Sin embargo, las autorizaciones también podrían ser objeto de procedimientos concursales cuando el interés público exige restringir el número de sujetos autorizados y existen más interesados. Un ejemplo típico sería el franchising de monopolios naturales $^{141}$ ( $v$. gr. servicios sanitarios ${ }^{142}$, transporte público de pasajeros en vías congestinadas ${ }^{143}$ ) o legales ( $v$. gr. casinos de juego).

También, autores como Parada sostienen que la autorización es distinta a la concesión en cuanto a que está abierta a todos los ciudadanos sin límites, "como ocurre, por ejemplo, en las licencias de conducir, de caza o de abrir establecimientos educativos, licencias urbanísticas, etc.". En cambio, en razón de su escasez, las licencias de taxis, farmacias, telecomunicaciones o importación serían más bien concesiones ${ }^{144}$ o, a lo menos, figuras híbridas ${ }^{145}$. Discrepamos de este criterio meramente cuantitativo, no solo porque descuida aspectos cualitativos relevantes, como la titularidad de la actividad, que determina si corresponde a un derecho protegido o a una expectativa, sino también porque pueden existir autorizaciones restringidas y concesiones de alta disponibilidad (v. gr. uso de terrenos fiscales).

\footnotetext{
139 CANASI 1974, 260. Sentencia TC Rol Nº 476 (2006), c. $41^{\circ}$.

140 Arancibia 2019, 329 y ss.

141 BaLdWIn Y LODGe 2012, 165.

142 Art. 14 y ss. de la Ley General de Servicios Sanitarios, D.F.L. N 382, Obras Públicas, de 1989.

143 Art. 3 de la Ley $N^{\circ} 18.696$, de 1988.

144 PARAda 2008, 383 y 384.

145 Se suele hablar de "concesiones autorizatorias", autorizaciones "concesionales" (GARcía 1991, 249), de autorizaciones "cuasicontractuales" (ZAGO 2000, 170), o de tertium genus (FuENTETAJA 2003, 101).
} 
Los reparos expuestos justifican la necesidad de explorar criterios alternativos de distinción entre autorización y concesión en el derecho nacional. Dado que ambos tipos de acto tienen un objeto declarativo y efectos constitutivos, pensamos que la distinción estriba más bien en la función de cada potestad, en su efecto constitutivo, en los riesgos de ganancia y pérdida, en la responsabilidad por daños de la actividad realizada, en su régimen de concursabilidad, y en el ámbito de injerencia estatal.

Así, mientras la autorización corresponde a una actividad estricta de policía, la concesión sirve para cumplir fines diversos de fomento, servicio público, empresa del Estado y policía ${ }^{146}$.

Por otro lado, la declaración autorizatoria produce la constitución de un derecho o interés legal reclamable al Estado de ejercer un derecho preexistente, sin perjuicio de los deberes legales anejos. La declaración concesional, en cambio, es apta para la constitución de un derecho legal sobre bienes nacionales o estatales, o de un gravamen legal respecto de actividades de titularidad estatal ${ }^{147}$, sin perjuicio de la constitución de deberes o derechos legales recíprocos.

En materia de riesgo de ganancia o pérdida y de responsabilidad por daños de la actividad habilitada, salvo norma en contrario, estos corresponden al titular de la misma, siendo el particular en caso de autorización y el Estado en hipótesis de concesión ${ }^{148}$. Lo anterior es sin perjuicio de la responsabilidad del Estado por falta de fiscalización del sujeto autorizado y del concesionario ante el Estado.

Por último, los deberes legales constituidos y precisados en virtud de un acto autorizatorio protegen a terceros respecto de los riesgos de la actividad. Aquellos relativos a la concesión, en cambio, se ordenan a los intereses del Estado como "titular" específico de la misma. Por lo mismo, el Estado no podría valerse de un régimen autorizatorio para exigir a los particulares condiciones propias de un concedente a un concesionario ${ }^{149}$.

\section{Frontera autorización-regulación}

La distinción entre autorización y regulación, si entendemos esta última como la imposición de obligaciones legales para satisfacer intereses públicos ${ }^{150}$, parece ser sencilla prima facie. En efecto, la primera consiste en un acto admi-

\footnotetext{
146 Véase Arancibia 2019, 354 y ss.

147 CASSAGNe 1995, 1182-1183. En nuestro país, esta tesis fue acogida por el Tribunal Constitucional en Sentencia Rol N 1413 (2009), c. 8. Ver también Moraga 2010, 311-314, y Vergara 2010, $239 ; 2018,48-52$.

148 ARIÑO 2005, 34-35.

149 ENTRENA 2013, 224.

150 KoOP y LOdge 2017, 95 a 108. Una definición similar ha sido adoptada por el Tribunal Constitucional en sentencias roles $N^{\circ} 146$ (1992), c. $9^{\circ}$, y $N^{\circ} 167$ (1993), c. $12^{\circ}$.
} 
nistrativo de beneficio, mientras que la segunda conlleva un acto legislativo ${ }^{151}$, susceptible de precisiones administrativas, de constitución de gravámenes a todo aquel que esté en posición o circunstancia de ser alcanzado por la norma.

Sin embargo, la distinción se vuelve más compleja, en primer término, cuando el acto autorizatorio precisa los deberes legales a los que estará sometido el sujeto autorizado. En este caso, el acto parece ser no solo declarativo sino también regulatorio. Empero, esta apreciación no deja de ser un espejismo jurídico, pues la regulación continúa siendo de fuente legal sin perjuicio de su necesaria precisión administrativa para el caso concreto. Un ejemplo típico de esta mixtura es la $\mathrm{RCA}^{152}$ y la resolución de aprobación de operaciones de concentración que dicta la Fiscalía Nacional Económica ${ }^{153}$. Ambas autorizan y precisan deberes legales para el desarrollo de una actividad.

Si bien el carácter híbrido de esta figura asegura una eficacia mayor en la prevención de riesgos, cabe preguntarse si el análisis de necesidad y proporcionalidad del acto debe ser también compuesto en razón de su duplicidad de fines. Esto se debe a que la finalidad de la autorización pura y simple es la prevención de riesgos de difícil corrección en razón de su entidad o costos de transacción involucrados, mientras que la de la regulación ex post suele ser la interacción eficiente o la prevención de riesgos corregibles. En consecuencia, la eficacia y proporcionalidad de las medidas prospectivas del acto autorizatorio deberían medirse conforme al segundo objetivo.

En segundo término, la distinción se ve desafiada en el caso de las autorizaciones legales o generales ${ }^{154}$, en virtud de las cuales un mismo cuerpo legal establece las condiciones iniciales bajo las cuales una actividad podría ser realizada. La normativa comunitaria europea la define como aquella "que no exija a la empresa interesada que recabe una decisión expresa de la autoridad nacional de reglamentación antes de ejercer los derechos que se derivan de la autorización"155. En nuestra opinión, sin embargo, la denominación de la ley como "autorizatoria" no deja de ser una mera analogía carente de valor técnico. Dado que la actividad no está sujeta a la carga de obtener una declaración administrativa previa, no existe una autorización propiamente tal.

\section{Conclusiones}

De acuerdo con lo expuesto en este trabajo, es posible destacar las siguientes conclusiones:

1. La autorización es un acto administrativo que legaliza el ejercicio de un derecho para el titular que cumple los requisitos legales condicionantes.

\footnotetext{
151 En razón de la reserva legal de la regulación económica prevista en el artículo $19 \mathrm{~N}^{\circ} 21$ de la Constitución.

152 Ley N 19.300, de 1994, Título II, Párrafo 2. Corte Suprema. Rol N²3.652-2014, c. $4^{\circ}$.

153 Arts. 54 y 57 del D.F.L. N 1, Ministerio de Economía, Fomento y Reconstrucción, de 2005.

154 MuÑoz 2010, 88 y ss.

155 Directiva 97/13/CE del Parlamento Europeo y del Consejo, de 1997, artículo 1 a).
} 
2. La técnica autorizatoria encuentra su justificación en actividades cuya realización no autorizada hace presumir riesgos de lesión al interés social difíciles de corregir de modo eficaz y eficiente mediante la imposición de poderes correctivos menos restrictivos.

3. La introducción de la potestad autorizatoria en un ámbito determinado da origen a una relación jurídica específica entre el solicitante y el Estado, regida por un estatuto legal que constituye derechos distintos e independientes al derecho cuyo ejercicio se pretende, así como gravámenes anejos al beneficio otorgado.

4. La estabilidad de un acto autorizatorio ante la modificación o extinción sobreviniente de sus efectos o régimen jurídico puede estar basada en un crédito de vigencia o en la confianza legítima en la inalterabilidad del acto.

5. Pese a que comparten elementos similares con las autorizaciones administrativas, los títulos legalizantes ope legis, concesionales y regulatorios no revisten una naturaleza autorizatoria.

\section{Bibliografía citada}

Arancibia Mattar, J. (2019). La concesión de bienes nacionales: concepto, objeto, fines y consecuencias prácticas. En J. Arancibia Mattar y P. Ponce Correa (coords.), El Dominio Público (pp. 327 a 375). Tirant lo Blanch.

Arancibia Mattar, J. (2017). La relación jurídica pública: íter conceptual, atributos y criterios. En E. Soto Kloss (coord.), El derecho administrativo y la protección de las personas (pp. 1-18). Ediciones UC.

Ariño Ortiz, G. (2005). La liberalización de los servicios públicos en Europa. Hacia un nuevo modelo de regulación para la competencia. En J.C. Cassagne y G. Ariño Ortiz (coords.). Servicios Públicos, Regulación y Renegociación (pp. 9-30). Lexis-Nexis Abeledo-Perrot.

Aróstica Maldonado, I. (2001). Derecho Administrativo Económico. Universidad Santo Tomás.

Arroyo Jiménez, L. (2004). Libre empresa y títulos habilitantes. CEPC.

Baddeley, M. (2017). Behavioural Economics. Oxford University Press.

Baldwin, R.; Cave, M. y Lodge, M. (2012). Understanding Regulation (2 ed.). Oxford University Press.

Bermúdez Soto, J. (2014). Fundamentos de Derecho Ambiental (2a ed.). Ediciones Universitarias de Valparaíso.

Bermúdez Soto, J. (2014). Derecho Administrativo General (3ª ed.). Thomson Reuters.

Biblioteca del Congreso Nacional (2018). Historia de la Ley N 19.300. Biblioteca del Congreso Nacional.

Black, J. and Baldwin, R. (2010). Really responsive risk-based regulation. Law and Policy, 32 (2), 181-213.

Blanquer Criado, D. (2018). La autorización y la comunicación (en el contexto de la UE). Tirant lo Blanch.

Canasi, J. (1974). Derecho Administrativo (Vol. II). Depalma.

Carmona Santander, C. (2003). Los Recursos de la Administración: Personal, Bienes y Presupuesto, Apuntes de Clases. $2^{a}$ parte. Universidad de Chile, Facultad de Derecho.

Carrasco Quiroga, E. y Herrera Valverde, J. (2014). La interpretación de la resolución de calificación ambiental. Revista Chilena de Derecho, 41(2), agosto, 635-671.

Cassagne, Juan C. (1995). El servicio público en las técnicas concesionales. La Ley, 11821183.

Cordero Quinzácara, E. (2020). Estudios sobre Propiedad y Derecho Urbanístico. Tirant Lo Blanch.

Cordero Vega, Luis (2015). Lecciones de Derecho Administrativo. Legal Publishing. 
Díaz de Valdés Juliá, J. M. y Enteiche Rosales, N. (2015). La estabilidad de los actos administrativos urbanísticos. Revista Actualidad Jurídica (31), 235-266.

Doménech Pascual, G. (2017). ¿Mejor antes o después? Controles públicos previos vs. Controles públicos posteriores. Papeles de Economía Española (151), 47-62.

Entrena Ruiz, Daniel (2013). El desarrollo de actividades en la vía pública en el contexto de la libre prestación de servicios. En L. Parejo Alfonso (Dir.), Autorizaciones y licencias, hoy (pp. 197-254). Tirant lo Blanch.

Figueroa Velasco, P. y Figueroa Valdés, J. E. (2006). Urbanismo y Construcción. Legal Publishing.

Fortes Martín, A. (2013). El régimen jurídico-administrativo de la licencia municipal de apertura. En L. Parejo Alfonso (Dir.), Autorizaciones y licencias, hoy (pp. 197-254). Tirant Lo Blanch.

Franco Escobar, S. (2017). La autorización administrativa en los servicios de interés económico general. Tirant lo Blanch.

Fuentes Olmos, J. (2012). Las autorizaciones de pesca y el derecho de propiedad. Revista de Derecho de la Pontificia Universidad Católica de Valparaíso, XXXVIII, Valparaíso, Chile, 1 er Semestre, 543-571.

Fuentetaja pastor, J. (2003). Elementos autorizatorios y concesionales en los títulos habilitantes. Revista de Administración Pública, enero-abril (160), 87-119.

García de Enterría, E. y Fernández, T. R. (2017). Curso de Derecho Administrativo (15 ed.) (T II). Civitas, Thomson.

García-Trevijano Fos, J. A. (1991). Los actos administrativos (2 $2^{\mathrm{a}}$ ed.). Civitas.

Giorgianni, M. (2018). La obligación. Ediciones Olejnik.

González Vergara, A. (1965). La concesión, acto administrativo creador de derechos. Editorial Jurídica de Chile.

Guiloff Titium, M. (2018). La expropiación regulatoria: Una doctrina impertinente para controlar la imposición de límites. lus et Praxis, Año 24 (2), 621-648.

Höppner, S., Kirchner, C. (2015). Ex ante versus ex post governance: a behavioral perspective. Review of Law and Economics, 227-259.

Koop, C. y Lodge, M. (2017). What is regulation? An interdisciplinary concept analysis? Regulation \& Governance (11), 95-108.

Laguna de Paz, J. C. (2006). La autorización administrativa. Thomson Civitas.

Mayer, O. (1982). Derecho Administrativo Alemán. T II. Parte Especial. Ediciones De Palma.

Mendoza Zúñiga, R. (1998). Acerca del control de la discrecionalidad técnica en materia eléctrica. Revista Chilena de Derecho, 25 (3), jul.-sept., 707-720.

Montt Oyarzún, S. (2010) (29 de julio de 2010). Informe en Derecho, "Expropiaciones directas y derregulatorias y reforma regulatoria pesquera". Disponible en http://derecho. uchile.cl/centro-de-regulacion-y-competencia/documentos/regulacion-y-derecho-publico-economico.html.

Moraga Klenner, C. (2010). Tratado de Derecho Administrativo, La actividad formal de la Administración del Estado. Abeledo-Perrot.

Muñoz Machado, S. (2010). Las transformaciones del régimen jurídico de las autorizaciones administrativas. Revista Española de la Función Consultiva (14), julio-diciembre, 85-110.

Ogus, A. (2004). Regulation: Legal Form and Economic Theory. Hart Publishing.

Orlando, V. E. (1979). Principios de Derecho Administrativo. Instituto Nacional de Administración Pública.

Parada Vásquez, J. R. (2008). Derecho Administrativo (17 ed.) (T I. Parte General). Marcial Pons.

Phillips Letelier, J. (2020). La protección de expectativas en el derecho administrativo chileno. Una propuesta para la aplicación del principio de protección. Tirant lo Blanch.

Rajevic Mosler, E. (2004). El Permiso de Construcción como Acto Administrativo. Acto y Procedimiento Administrativo, Segundas Jornadas de Derecho Administrativo. Ediciones Universitarias de Valparaíso.

Ranelletti, O. (1894). Teoria generale delle autorizzazioni e concessioni amministrative. Parte I. Concetto e natura. Edit. Unione Tipografico Editrice, F.lli Bocca. 
Real Academia Española de la Lengua, Consejo General del Poder Judicial (2019). Diccionario del Español Jurídico, S. Muñoz Machado (Dir.). Editorial Planeta.

Soto Kloss, E. (2000). Comentario al fallo Sociedad Educacional San Esteban S.A. con Secretario Ministerial Metropolitano de Vivienda y Urbanismo (S) y Director de Obras de la Municipalidad de Colina s/ Recurso de protección", en: Microjuris Chile, Cita: RDJ356, MJJ356.

Soto Kloss, E. (2012). Derecho Administrativo Temas Fundamentales ( $3^{\mathrm{a}}$ ed. actualizada). Thomson Reuters.

Soto Kloss, E. (2014). Inestabilidad del acto administrativo y derechos de los destinatarios (a propósito del artículo 53 inciso $1^{\circ}$ de la Ley N ${ }^{\circ} 19.880$ ). En E. Soto Kloss (coord.), Administración y Derecho (pp. 283-297). Thomson Reuters La Ley.

Vaquer Caballería, M. (2013). Las licencias de obras. En L. Parejo Alfonso (Dir.), Autorizaciones y licencias, hoy (pp. 41-88). Tirant lo Blanch.

Vergara Blanco, A. (2004). El nuevo servicio público abierto a la competencia: de la publicatio al libre acceso. Coherencia de las viejas técnicas concesional y autorizacional. Revista de Derecho Administrativo Económico (12), 33-49.

Vergara Blanco, A. (2010). Instituciones de Derecho Minero. AbeledoPerrot LegalPublishing.

Vergara Blanco, A. (2018). Derecho Administrativo Económico. Thomson Reuters.

Viñuela Hojas, M. (2005). La estabilidad de los permisos otorgados al amparo de la Ley General de Urbanismo y Construcciones frente a modificaciones de los instrumentos de planificación territorial dispuestas por la autoridad ambiental. Revista de Derecho Administrativo Económico (15), 103-112.

Zago, T. (2000). Las licencias individuales (I): Régimen jurídico general. En J. M. De la Cuétara, R. Ariño y T. Zago, Autorizaciones y licencias en Telecomunicaciones. Su regulación presente y futura (pp. 167-210). Fundación Estudios de Regulación/Comares.

\section{Normativa citada}

Constitución Política de la República [CPR]. 17 de septiembre de 2005 (Chile).

Decreto $N^{\circ} 206$ de 1960 [con fuerza de ley]. Fija el texto refundido de las disposiciones legales sobre construcción, conservación y financiamiento de caminos; deroga la Ley $\mathrm{N}^{\circ}$ 4.851. 26 de marzo de 1960. D.O. N 24.612.

Decreto N 323 de 1931 [con fuerza de ley]. Ley de Servicios de Gas. 20 de mayo de 1931. D.O. $\mathrm{N}^{\circ} 15.976$.

Decreto $\mathrm{N}^{\circ} 340$ [con fuerza de ley]. Sobre concesiones marítimas. 5 de abril de 1960. D.O. $N^{\circ} 24.613$.

Decreto N 382 [con fuerza de ley]. Ley General de Servicios Sanitarios. 30 de diciembre de 1988. D.O. N $N^{\circ} 33.403$.

Decreto $\mathrm{N}^{\circ} 4$ [con fuerza de ley]. Fija texto refundido, coordinado y sistematizado de Ley General de Servicios Eléctricos. 12 de mayo de 2006. D.O. № 38.461.

Decreto $N^{\circ} 850$ [con fuerza de ley]. Obras Públicas, fija el texto refundido y sistematizado de la Ley No 15.840, de 1964 y del D.F.L. N²06, de 1960. 12 de septiembre de 1997. D.O. $\mathrm{N}^{\circ} 36.000$.

Decreto $N^{\circ} 1$ [con fuerza de ley]. Economía, Fomento y Reconstrucción, fija el texto refundido, coordinado y sistematizado del D.L. N²11 de 1973. 17 de diciembre de 1973. D.O. $\mathrm{N}^{\circ} 38.104$.

Decreto $\mathrm{N}^{\circ} 1$ [con fuerza de ley]. Justicia, fija texto refundido, coordinado y sistematizado del Código Civil. 16 de mayo de 2000. D.O. N³6.676.

Decreto $N^{\circ} 1$ [con fuerza de ley]. Transportes y Telecomunicaciones, fija texto refundido, coordinado y sistematizado de la Ley de Tránsito. 27 de diciembre de 2007. D.O. $N^{\circ} 39.498$.

Decreto $\mathrm{N}^{\circ} 1$ [con fuerza de ley]. Interior, fija el texto refundido, coordinado y sistematizado de la Ley $N^{\circ}$ 18.695, Orgánica Constitucional de Municipalidades. 9 de mayo de 2006. D.O. No 38.523. 
Decreto No 323 [con fuerza de ley]. Ministerio del Interior, Ley de Servicios de Gas. 20 de mayo de 1931. D.O. $\mathrm{N}^{\circ} 15.984$.

Decreto N 458 [con fuerza de ley] aprueba Nueva Ley General de Urbanismo y Construcciones. 18 de diciembre de 1975. D.O. N²9.431.

Decreto $\mathrm{N}^{\circ} 2$ de 2009 [con fuerza de ley]. Fija texto refundido, coordinado y sistematizado de la Ley $\mathrm{N}^{\circ} 20.370$ con las normas no derogadas del D.F.L. $N^{\circ} 1$, de 2005. 16 de diciembre de 2009. D.O. N³9.700.

Decreto No 1094 de 1975 [Ministerio del Interior]. Establece normas sobre extranjeros en Chile. 14 de julio de 1975.

Decreto No 1939 [Ministerio de Tierras y Colonización]. Normas sobre Disposición de bienes del Estado. 5 de octubre de 1977.

Decreto № 2224 [Ministerio de Minería]. Crea el Ministerio de Energía y la Comisión Nacional de Energía. 25 de mayo de 1978.

Decreto $N^{\circ} 2385$ [Ministerio del Interior]. Fija texto refundido y sistematizado del D.L $N^{\circ} 3.063$, de 1979, sobre rentas municipales. 30 de mayo de 1996.

Decreto No 212 [Ministerio de Transportes y Telecomunicaciones]. Reglamento de los Servicios Nacionales de Transporte Público de Pasajeros. 15 de octubre de 1992.

Decreto $N^{\circ} 430$ [Economía, Fomento y Reconstrucción]. Fija el texto refundido, coordinado y sistematizado de la Ley General de Pesca y Acuicultura. 28 de septiembre de 1991.

Decreto No 4 [Vivienda y Urbanismo]. Ordenanza General de la Ley General de Urbanismo y Construcciones. 16 de abril de 1992.

Ley N 18.168 de 1982. Ley General de Telecomunicaciones. 15 de septiembre de 1982. D.O. N $\mathrm{N}^{\circ} 39.700$.

Ley $N^{\circ} 18.410$ de 1985. Crea la Superintendencia de Electricidad y Combustibles. 26 de abril de 1985. D.O. No 32.176 .

Ley $N^{\circ} 18.696$. Modifica artículo $6^{\circ}$ de la Ley $N^{\circ} 18.502$, autoriza importación de vehículos que señala y establece normas sobre transporte de pasajeros. 30 de marzo de 1998. D.O. N $N^{\circ} 33.035$.

Ley $N^{\circ} 19.040$. Establece normas para adquisición por el Fisco de vehículos que indica y otras disposiciones relativas a la locomoción colectiva de pasajeros. 23 de enero de 1991. D.O. N $N^{\circ} 33.877$.

Ley N ${ }^{\circ}$ 19.300. Aprueba Ley sobre Bases Generales del Medio Ambiente. 1 de marzo de 1994. D.O. No 34.810.

Ley $N^{\circ} 19.542$, moderniza el sector portuario estatal. 9 de diciembre de 1997. D.O. $N^{\circ} 35.944$.

Ley N ${ }^{\circ}$ 19.995. Establece las Bases Generales para la Autorización, Funcionamiento y Fiscalización de Casinos de Juego. 4 de enero de 2005. D.O. № 38.054.

Ley $\mathrm{N}^{\circ} 20.129$. Establece un sistema nacional de aseguramiento de la calidad de la educación superior. 23 de octubre de 2006. D.O. №38.616.

Ley $N^{\circ} 20.720$. Sustituye el régimen concursal vigente por una ley de reorganización y liquidación de empresas y personas, y perfecciona el rol de la superintendencia del ramo. 30 de diciembre de 2013. D.O. No 40.752.

Mensaje de S.E. el Presidente de la República con el que se inicia un proyecto de ley que establece el Régimen Especial de Pesca, Boletín 2274-03, 2 de diciembre de 1998.

Directiva $N^{\circ}$ 97/13/CE del Parlamento Europeo y del Consejo, relativa a un marco común en materia de autorizaciones generales y licencias individuales en el ámbito de los servicios de telecomunicaciones. Diario Oficial, 7 mayo 1997.

Directiva $N^{\circ} 2004 / 67$ del Consejo, relativa a unas medidas para garantizar la seguridad del suministro de gas natural. Diario Oficial 29 abril 2004.

Directiva $N^{\circ}$ 2006/48/CE del Parlamento Europeo y del Consejo, relativa al acceso a la actividad de las entidades de crédito y a su ejercicio (refundición). 30 junio 2006.

Directiva No 2006/123/CE del Parlamento Europeo y del Consejo, relativa a los servicios en el mercado interior. 27 diciembre 2006. 
Directiva N ${ }^{\circ}$ 2009/140/CE del Parlamento Europeo y del Consejo, relativa a un marco regulador común de las redes y los servicios de comunicaciones electrónicas. 25 de noviembre de 2009.

\section{Jurisprudencia citada}

Corte Suprema. Rol No 10.859-1987, 24 noviembre 1987.

Corte Suprema. Tercera Sala. Rol No 33.611-1996, 9 enero 1996.

Corte Suprema. Tercera Sala. Rol No 1.469-1999, 27 julio 1999.

Corte Suprema. Tercera Sala. Rol No 1.428-2007, 16 octubre 2008.

Corte Suprema. Tercera Sala. Rol No 552-2013, 25 septiembre 2013.

Corte Suprema. Tercera Sala. Rol No 4.800-2007, 29 septiembre 2007.

Corte Suprema. Tercera Sala. Rol No 21.183-2014, 18 marzo 2015.

Corte Suprema. Tercera Sala. Rol No 23.652-2014, 22 junio 2015.

Corte Suprema. Tercera Sala. Rol No 434-2015, 22 julio 2015.

Corte Suprema. Tercera Sala. Rol No 58.992-2016, 30 marzo 2017.

Corte Suprema. Tercera Sala. Rol № 2.138-2012, 27 de julio de 2012.

Corte Suprema. Tercera Sala. Rol No 2.551-2018, 22 febrero 2018.

Corte Suprema. Tercera Sala. Rol NN 11.485-2017, 5 marzo 2018.

Corte Suprema. Tercera Sala. Rol No 36.684-2017, 22 enero 2019.

Corte Suprema. Tercera Sala. Rol No 8.136-2018, 23 julio 2018.

Corte Suprema. Tercera Sala. Rol No 31.594-2018, 1 julio 2019.

Corte Suprema. Tercera Sala. Rol No 31.797-2018, 20 marzo 2020.

Corte Suprema. Tercera Sala. Rol No 29.945-2018, 15 abril 2020.

Corte Suprema. Tercera Sala. Rol No 20.969-2020, 26 mayo 2020.

Corte Suprema. Tercera Sala. Rol N 50.662-2020, 30 junio 2020.

Corte Suprema. Tercera Sala. Rol No 34.788-2016, 2 febrero 2017.

Corte Suprema. Tercera Sala. Rol Nº 5202-2005, 27 octubre 2005.

\section{Tribunal Constitucional}

Tribunal Constitucional. Rol No 146-92, 21 abril 1992.

Tribunal Constitucional. Rol No 167-93, 6 abril 1993.

Tribunal Constitucional. Rol No 437-05, 21 abril 2005.

Tribunal Constitucional. Rol № 467-06, 14 noviembre 2006.

Tribunal Constitucional. Rol No 476-06, 17 abril 2006.

Tribunal Constitucional. Rol No 718-07, 26 noviembre 2011.

Tribunal Constitucional. Rol No 1.991-11, 20 abril 2011.

Tribunal Constitucional. Rol No 1.199-08, 1 septiembre 2008.

Tribunal Constitucional. Rol No 1.363-09, 28 julio 2009.

Tribunal Constitucional. Rol No 1.413-09, 16 noviembre 2010.

Tribunal Constitucional. Rol No 1.452-09, 5 agosto 2010.

Tribunal Constitucional. Rol No 2.069-11, 31 julio 2012.

Tribunal Constitucional. Rol No 2.731-14, 26 noviembre 2014.

Tribunal Constitucional. Rol No 2.841-15, 21 enero 2016.

Tribunal Constitucional. Rol No 3.208-16, 3 abril 2018.

Tribunal Constitucional. Rol No3.250-16, 3 abril 2018.

Tribunal Constitucional. Rol No 5.172-18, 14 mayo 2019.

Tribunal Constitucional. Rol No 8.614-20, 12 de noviembre de 2020.

\section{Contraloría General de la República}

Contraloría General de la República. Dictamen N²8.151, 20 de agosto de 1998.

Contraloría General de la República. Dictamen N 17.393, 12 de mayo de 1999.

Contraloría General de la República. Dictamen N²3.701, 1 de julio de 1999.

Contraloría General de la República. Dictamen Nº 610, 7 de enero de 2000. 
Contraloría General de la República. Dictamen N5.230, 11 de febrero de 2000. Contraloría General de la República. Dictamen N 8.360, 9 de marzo de 2000. Contraloría General de la República. Dictamen N 15.089, 2 de mayo de 2000. Contraloría General de la República. Dictamen N³4.124, 2 de septiembre de 2002. Contraloría General de la República. Dictamen N²0.477, 20 de mayo de 2003. Contraloría General de la República. Dictamen N³4.021, 11 de agosto de 2003. Contraloría General de la República. Dictamen N 17.033, 11 de abril de 2005. Contraloría General de la República. Dictamen No 12.664, 21 de marzo de 2006. Contraloría General de la República. Dictamen N 40.152, 28 de junio de 2011. Contraloría General de la República. Dictamen N65.813, 18 de octubre de 2011. Contraloría General de la República. Dictamen N 48.722, 9 de agosto de 2012.

Contraloría General de la República. Dictamen N 60.482, 23 de septiembre de 2013. Contraloría General de la República. Dictamen N42.836, 29 de mayo de 2015. Contraloría General de la República. Dictamen Nº 87.452, 4 de noviembre de 2015. Contraloría General de la República. Dictamen N 14.249, 7 de junio de 2018.

\section{Tribunal de Justicia de la Unión Europea}

Luisi y Carbone, C-286/82 y C-26/83, 31 enero 1984.

Bordessa y otros, C-358/93 y C-416/93, 23 febrero 1995.

Sanz de Lera, C-163/94, C-165/94 y C-250/94, 14 diciembre 1995.

Konle, C-302/97, 1 junio 1999.

Asociación Profesional de Empresas Navieras de Líneas Regulares (Analir) and Others v Administración General del Estado, C-205/99, 20 febrero 2001.

Smits y Peerbooms, C-157/99, 12 julio 2001.

Canal Satélite Digital SL v Administración General del Estado, C-390/99, 22 enero 2002.

Comisión v Bélgica, C-503/99, 4 junio 2002.

Comisión v Francia, C483/99, 4 junio 2002.

Comisión v Portugal, C-367/98, 4 junio 2002.

Comisión con España, C-463/00, 13 mayo 2003.

Monsanto Agricoltura Italia y otros, C-236/01, 9 septiembre 2003.

Comisión v Dinamarca, C-192/01, 23 septiembre 2003.

Comisión v Francia, C-122/03, 11 diciembre 2003.

Germany GmbH y Arcor AG \& Co. KG v Alemania, C-392/04 y C-422/04, 19 septiembre 2006.

Comisión v España, C-274/06, 14 febrero 2008.

Comisión v Reino de España, C-207/07, 17 julio 2008.

Comisión v Austria, C-169/07, 10 marzo 2009.

Comisión v Italia, C-326/07, 26 marzo 2009.

Comisión v Holanda, C-567/07, 1 octubre 2009.

Comisión v Francia, C-333/08, 28 enero 2010.

Naftiliaki Etaireia Thasou AE and Amaltheia I Naftiki Etaireia v Ypourgos Emporikis Naftilías, C-128/10 y C-129/10, 17 marzo 2011.

Comisión v Alemania, C-39/11, 7 junio 2012.

Comisión v Grecia, C-244/11, 8 noviembre 2012.

Comisión v Reino Unido, C-316/15, 16 noviembre 2016.

Comisión v Alemania, C-282/15, 19 enero 2017.

Comisión v Bélgica, C-137/17, 26 septiembre 2018. 